\title{
THE EPIDEMIOLOGY OF FOX RABIES IN EUROPE
}

\section{FRANZ STECK AND ALEXANDER WANDELER'}

Rabies virus is a very old parasite of animals and humans. Records dating back to 2300 years $\mathrm{BC}$ document that rabies was prevalent and recognized as a disease transmitted from dogs to humans in ancient Babylon, with the same epidemiologic features as today. Rabies virus strains from such divergent hosts as bats or foxes show very strong cross-reaction in serum neutralization in all parts of the world. This would suggest that rabies virus has not substantially changed in 4000 years of observation. Recently, Wiktor and Koprowski (1) demonstrated strain differences by the use of monoclonal antibodies. However, this method has not yet been applied to epidemiologic studies.

How can such a disease agent, which usually kills its host, survive? Two basic features of rabies appear to play a key role in the perpetuation of the virus: one is the peculiar pathway of infection which in most infected animals avoids the stimulation of an immune response until late in the fatal course of the disease (2), thus preventing the creation of an immune population $(3,4)$, and the other is the high dependence on the population density of the main vector species, where

\footnotetext{
Abbreviations: IC, intracerebral; IM, intramuscular; MICLD Mo , mouse intracerebral 50 per cent lethal dose.

'Vet.-Bakteriologisches Institut, Schweiz. Tollwutzentrale, Unniversität Bern, Länggassstr. 122, 3012 Bern, Switzerland.

This work has been supported by the Swiss Federal Veterinary Office, Bern, Switzerland, and the World Health Organization, Veterinary Public Health Service, Geneva.

The authors thank Drs. K. Bögel, H. Moegle, K. Dietz, H. Burri, and M. Gessler for their permission to include some of their results in this study; $B$. Nydegger for technical assistance; and U. B. Holderegger, M. Martin, M. Kohler, and L. Lagher for the preparation of this manuscript and the drawings.
}

the chain of infection is interrupted long before the host species becomes extinct $(5-8)$.

In this review we give an account of the epidemiology of fox rabies in Europe and try to explain the intimate links between the dynamics of the disease and the biology and ecology of foxes. The typical pattern of the rabies epizootic has stimulated the development of computer simulations. Some of these approaches have been discussed by Toma and Andral (9) and will not be included in this review.

\section{The SPREAD OF Rabies}

Starting from endemic foci in northwestern Poland $(10,11)$, a rabies epizootic whose main vector is the fox (12) has spread east, south and west. It has invaded large parts of central, eastern and western Europe in the last 40 years (figure 1) $(13,14)$. Figure 2 shows the geographic distribution of rabies outbreaks occurring during the last quarter of 1979 (20) in central and western Europe. Only limited information is available on the eastward spread into the Union of Soviet Socialist Republics (USSR). Moving from Poland and the Kalinin district into Lithuania and Latvia, the epizootic reached Estonia in 1968. Byelorussia and the Ukraine were invaded after 1963.

According to Selimov et al. (72), a second focus of infection was observed simultaneously in the Astrakhan region of the Volga delta, from which rabies spread in eastern, northern and western directions. Natural foci of fox rabies are found today in the Baltic republics, Byelorussia, Russian Socialist Republic south $56^{\circ}$ latitude from Kaliningrad to the Khabarovsk region, in the Ukraine and Kasachstan.

Fox rabies thus far has reached Poland, the USSR, the German Democratic Re- 


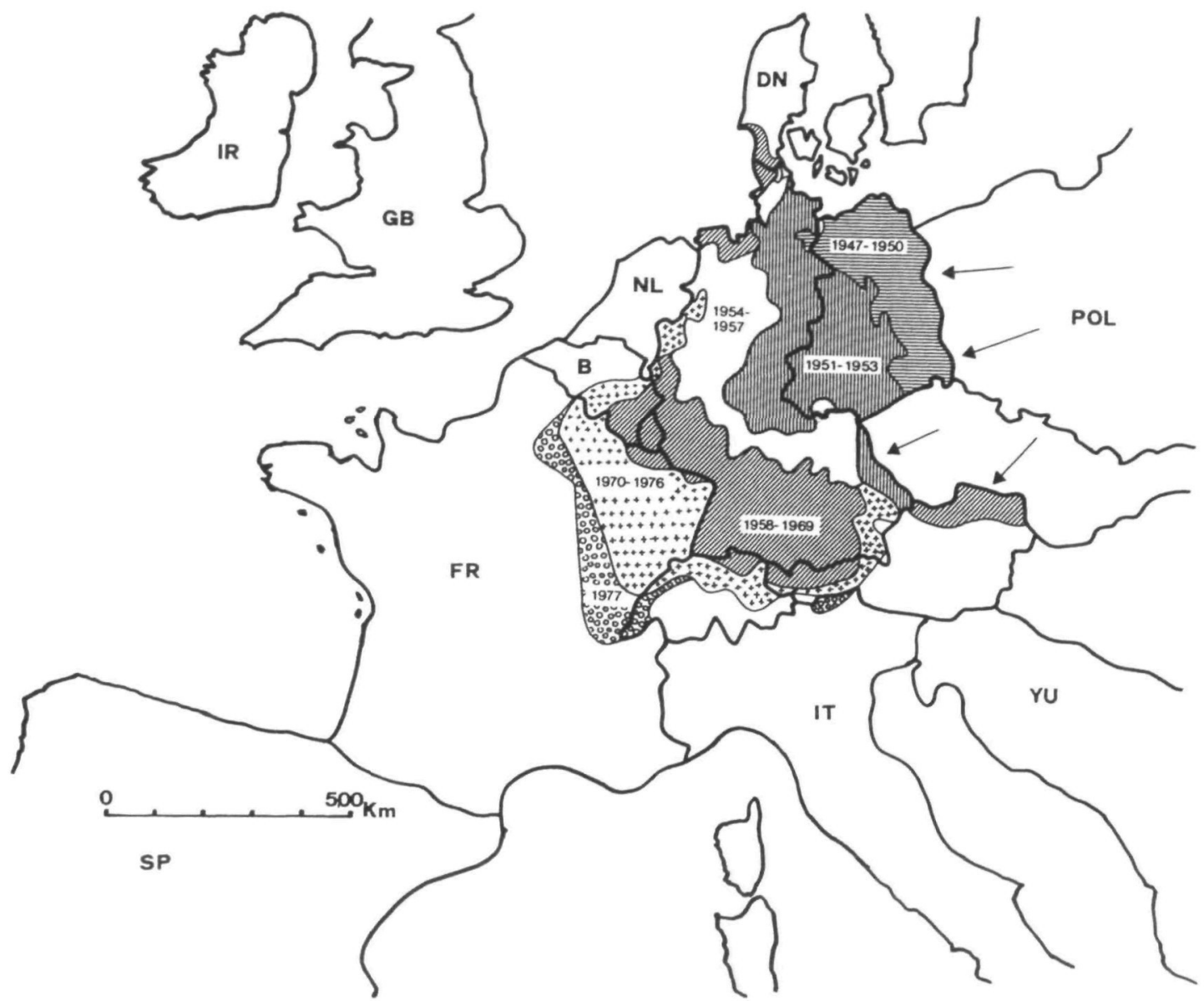

FIGURE 1. Spread of fox rabies in Europe, 1947-1977. (B = Belgium; DN = Denmark; FR = France; GB = Great Britain; IR = Ireland; IT = Italy; NL = the Netherlands; POL = Poland; SP = Spain; YU = Yugoslavia.)

public, Czechoslovakia, Austria, the Federal Republic of Germany, Hungary, Yugoslavia, Switzerland, Denmark, Belgium, Luxembourg, France, and Italy. In the Netherlands fox rabies has been limited to a very small border zone. Only a few countries-Great Britain, Finland, Ireland, Norway and Sweden-have remained essentially rabies free, with the exception of isolated (imported) cases.

It is particularly noteworthy that the newly invaded areas had been free of wildlife rabies for at least 50-100 years. There were, however, several reports on fox rabies epizootics during the last cen- tury $(15,16)$. The descriptions of an epizootic in Switzerland by Streiff in 1829 (17) and Köchlin in 1835 (18) are in most details reminiscent of the present situation. The factors which thereafter led to the complete disappearance of rabies among foxes are unknown. Nor is it understood which events initiated the present epizootic and precisely where it originated.

Dog rabies, which is still endemic in some parts of eastern and southeastern Europe, is not directly linked with the epizootic among foxes and shall not be discussed in this review. A recent sum- 


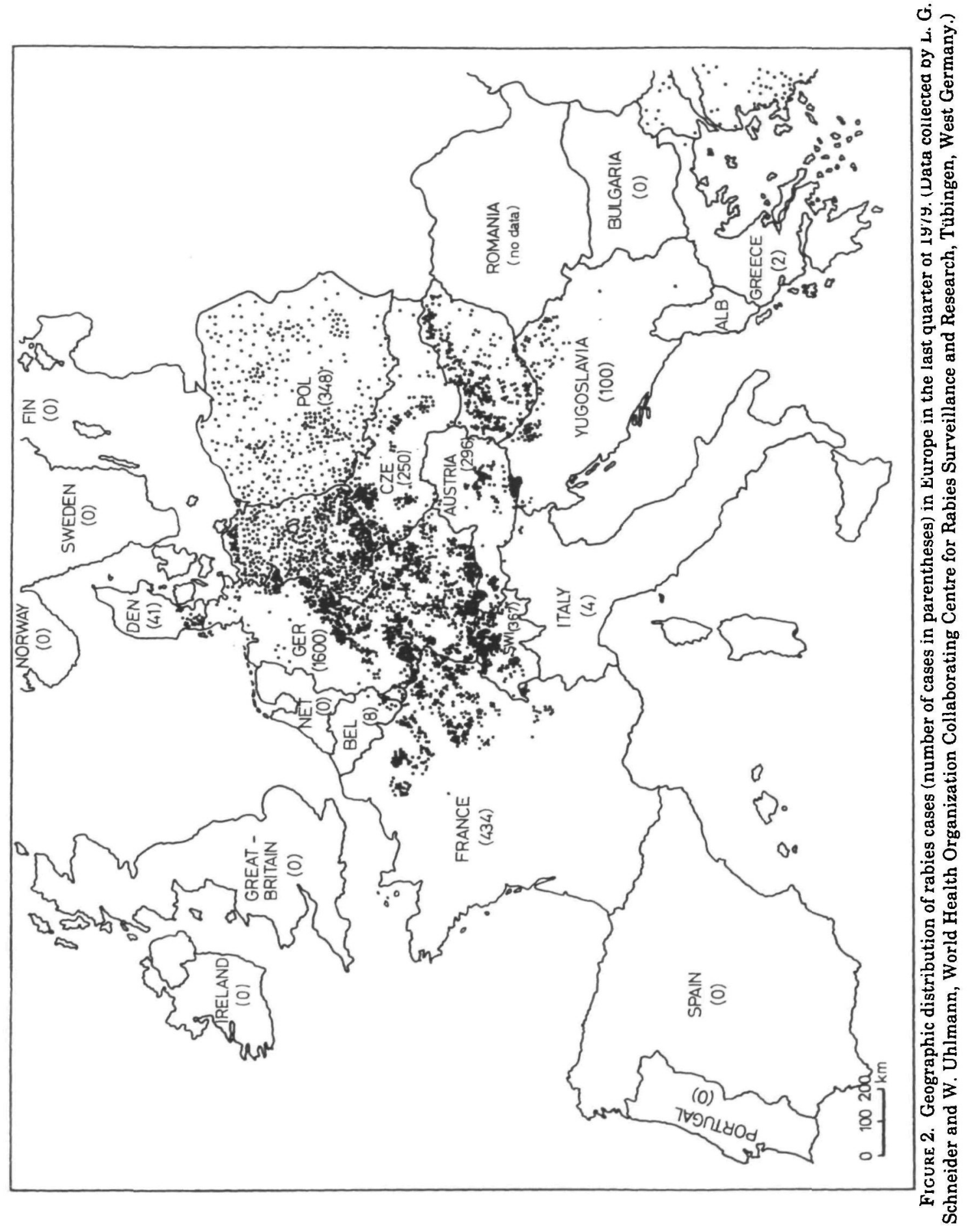


mary on the rabies situation in the World Health Organization (WHO) European region was presented in 1977 by Wachendörfer (19).

Dog rabies was brought under control by the turn of the century in most parts of northern and western Europe. Through compulsory dog vaccination campaigns initiated in Hungary in 1935, in Poland in 1947-1948, and in Czechoslovakia in 1948 , dog rabies was drastically reduced, but without effect on the increasing incidence of fox rabies $(14,15)$. The general concern about this new rabies invasion has stimulated a close surveillance of the epizootic, particularly of the frontwave moving into virgin countries.

The movement of the frontwave has been irregular but continual, modified only by natural barriers of which the common denominator appears to be a low fox population density. In its southwestbound spread the frontline has advanced about $1400 \mathrm{~km}$ in 38 years, an average of $37 \mathrm{~km}$ per year. The shift of the front has varied between a temporary standstill and a progression of $60-80 \mathrm{~km}$ per year. In a computer analysis by Bögel et al. (21), the mean monthly distance in which new cases were found beyond the frontline was $4.8 \mathrm{~km}$, regardless of the relative fox population density above a critical threshold. Maximum monthly spread was $20 \mathrm{~km}$.

In Switzerland there was one instance of a buildup of a new focus $48 \mathrm{~km}$ ahead of the nearest rabies front (22). In the frontwave situation each major movement was usually preceded by a high infection rate in the adjacent infected area (21) (figure 3). There was a marked slowdown of spread between April and July. We compared the surface of the new areas covered by the rabies epizootic each quarter in Switzerland to the total annual progression: 28 per cent were invaded in the first quarter, only 13 per cent in the second, and 27 and 31 per cent in the third and fourth quarters, respectively. Correc- tions were made for differences in the length of the starting line. The reduced spread during April, May and June is highly significant $(p<0.001)$. This is particularly interesting since the total fox population reaches its maximum at this time, immediately after the whelping season. Possible explanations for this phenomenon will be discussed later in this review.

In areas of low fox population density these chains of infection, however, are interrupted (figure 4). Major obstacles to the spread of rabies (apart from oceans) are areas of small game hunting, where the fox population is kept low through intensive hunting (23), and the high alpine region with its biologic limitations (22).

With few exceptions none of the regions behind the frontwave have become permanently free of rabies in the last 40 years. The frontwave has usually been followed by 3-5 years of low incidence or by the absence of rabies due to a drastic reduction of the fox population, but the periodic reappearance of rabies has occurred thereafter (9) (figures 5,6). The pattern of reappearance of rabies behind the front is less dramatic, consisting of irregular foci and waves of spread in many directions (figure 2) linked with a recovered fox population.

The spread of the infection is a function of the activity range of (rabid) foxes. The peculiar mode of transmission by bite or intensive contact with infectious saliva limits actual transmiśsion to only a small fraction of social contacts and to a rather short time in the course of infection, and finally, as discussed above, to fox population density. Some of these factors will be discussed further.

INVOLVEMENT OF ANIMAL SPECIES

The relative and absolute frequency in which different animal species are found to be affected by rabies is, of course, subject to the bias of the sample. Intensive surveillance of this epizootic with some 

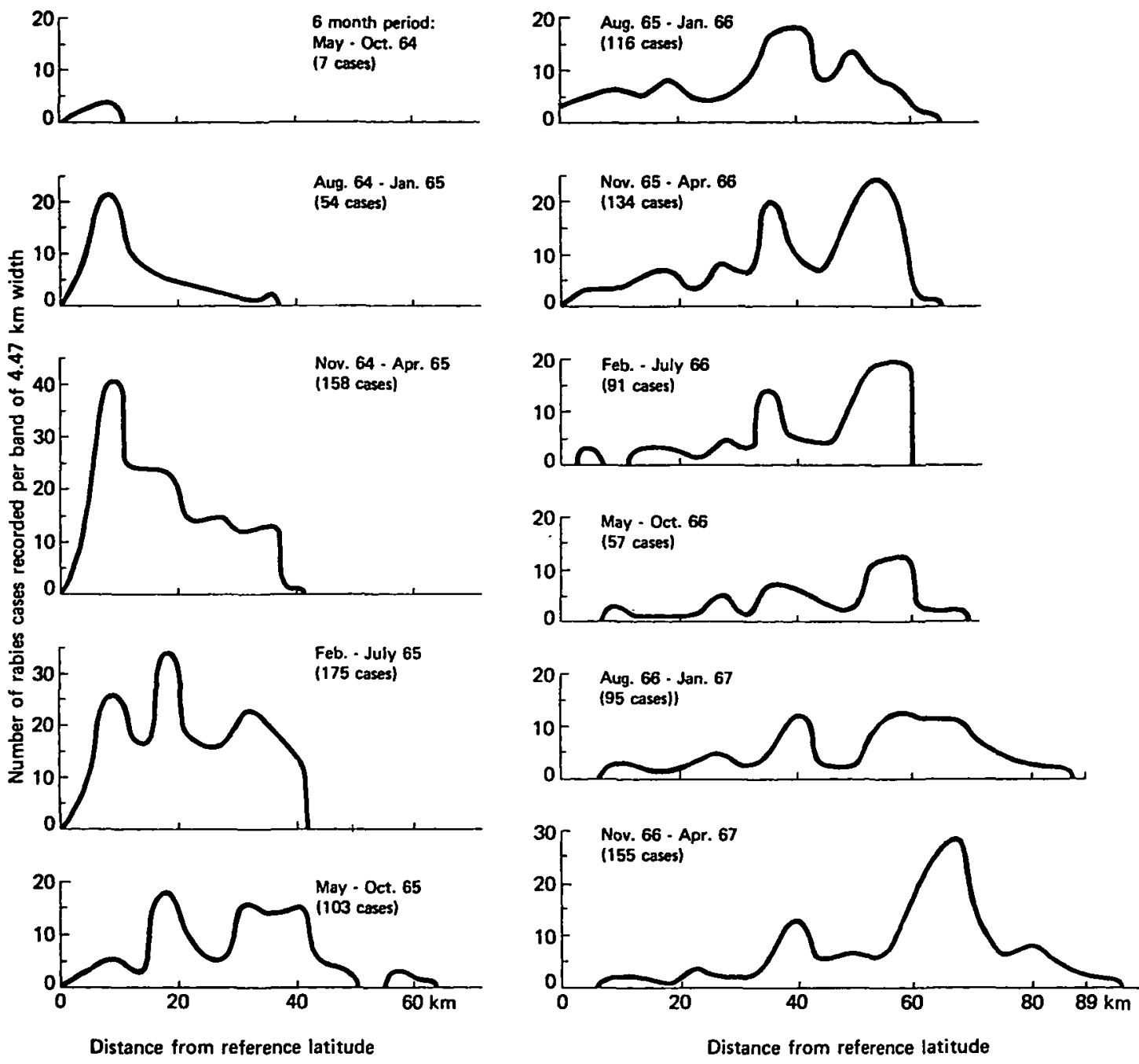

Figure 3. Movement of the epidemic frontwave of rabies through a zone approximately $50 \mathrm{~km}$ wide in Baden-Wurttemberg, West Germany. The incidence of rabies cases and their distance from an arbitrarily chosen reference latitude of $5383.480 \mathrm{~km}$ were recorded from May 1964 to April 1967 during the north-south movement of the epizootic wave. Cases for six-month periods are shown in successive intervals of three months. The band width was determined by the printout conditions of the computer. (Source: reference 21.)

corrections for the sampling has confirmed the predominant role of foxes in this outbreak $(7,9,13,14,16,52,53)$ (table 1).

In several parts of the USSR, a high incidence of rabies is found in raccoon dogs (Nyctereutes procyonoides), in addition to that found in foxes. This species nevertheless does not appear to give rise to epizootic cycles independent of foxes (73).
Foxes constitute at least $83-85$ per cent of all recorded cases of rabies in this European epizootic. About 10 per cent are found in other wildlife, particularly in roe deer, badgers and stone martens, and only 5-10 per cent in domestic animals $(7,16$, 22). In most surveys a lower percentage of rabies infected foxes is found. This is mainly due to underreporting in foxes and 


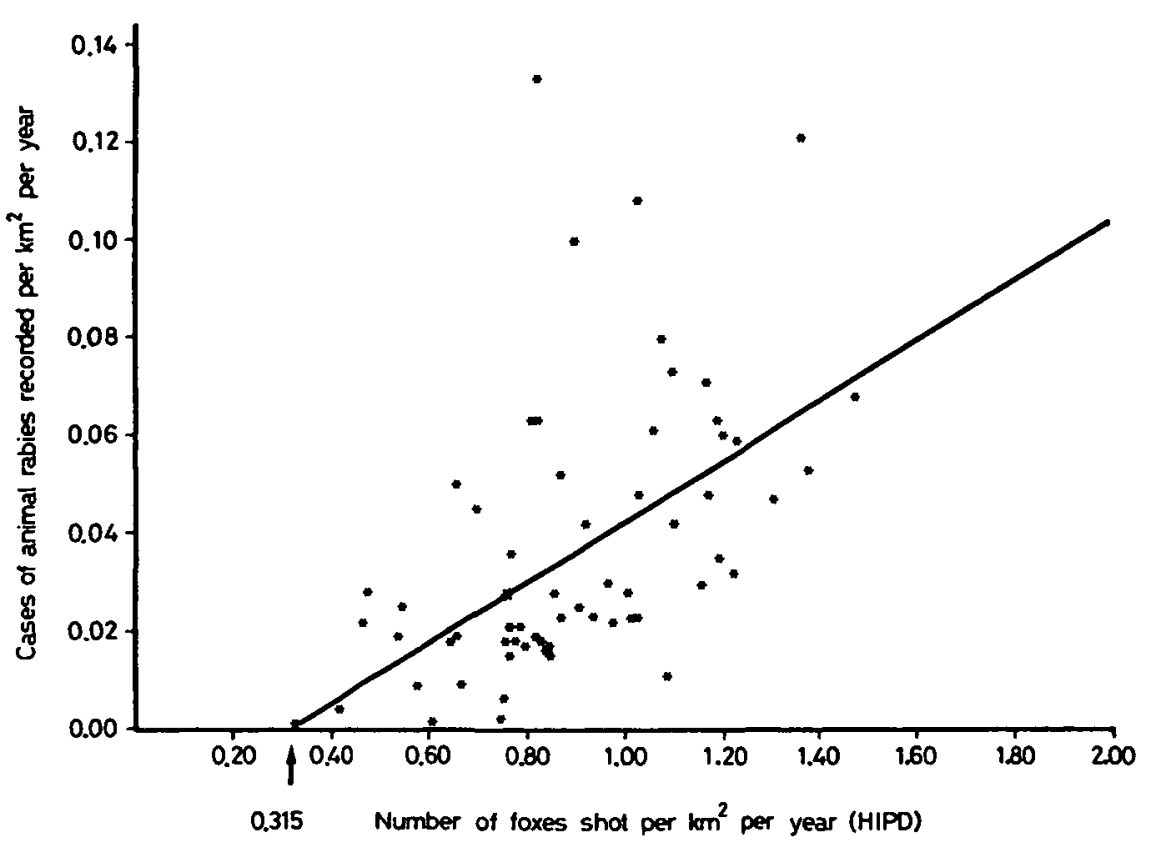

Figure 4. Regression of the frequency of animal rabies according to the hunting indicator of fox population density (HIPD) in 62 districts of Baden-Württemberg, West Germany. Rabies incidence in relation to fox hunting statistics as indirect estimates of fox population density. (Source: reference 8.) Data from the 62 districts were submitted to regression analysis which indicated that zero incidence of rabies is reached at 0.3-0.4 foxes per sq $\mathrm{km}$ killed annually by hunting. $\left(^{*}=\right.$ each district.)

high reporting in domestic animals. Sporadic cases of rabies, involving only a few individual animals in the last 25 years, have been found in other wildlife species.
The analysis of the frontwave shows that foxes bring the infection into new areas $(13,16,21,25)$. Of all rabies cases appearing before a given monthly frontline, 97.2 per cent are foxes, whereas

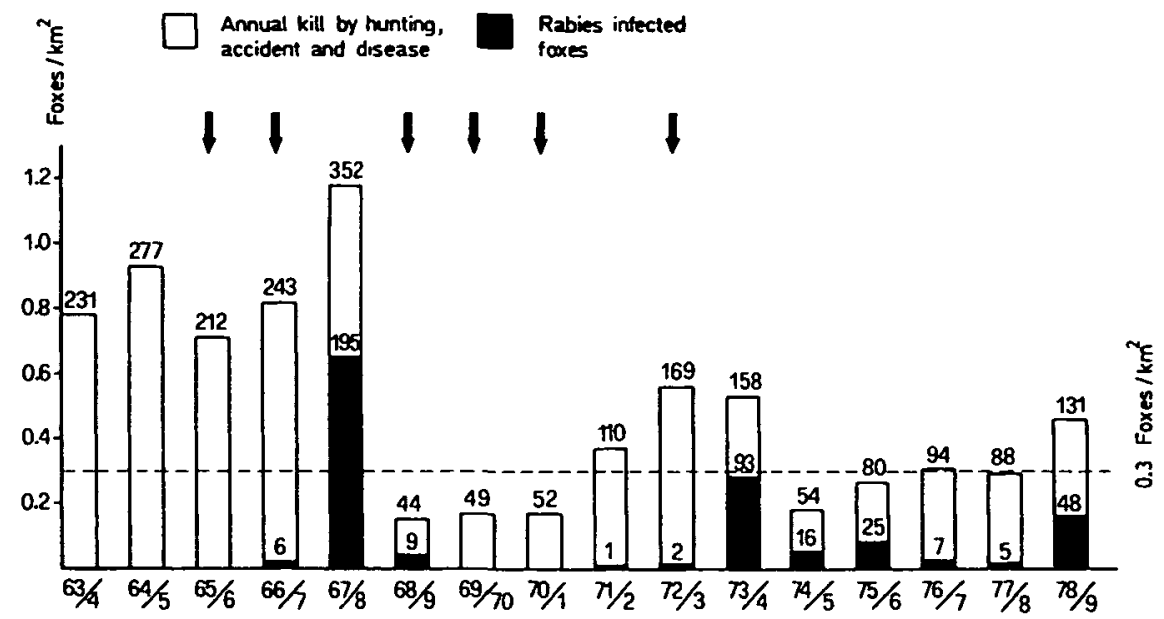

Ficure 5. Annual fox hunting and incidence of rabies in the canton of Schafthausen, Switzerland, 1963/ 1964-1978/1979. Three major waves of rabies moved through this area of $298 \mathrm{sq} \mathrm{km}$ at five- to six-year intervals, causing a reduction of the fox population followed by a gradual recovery. 


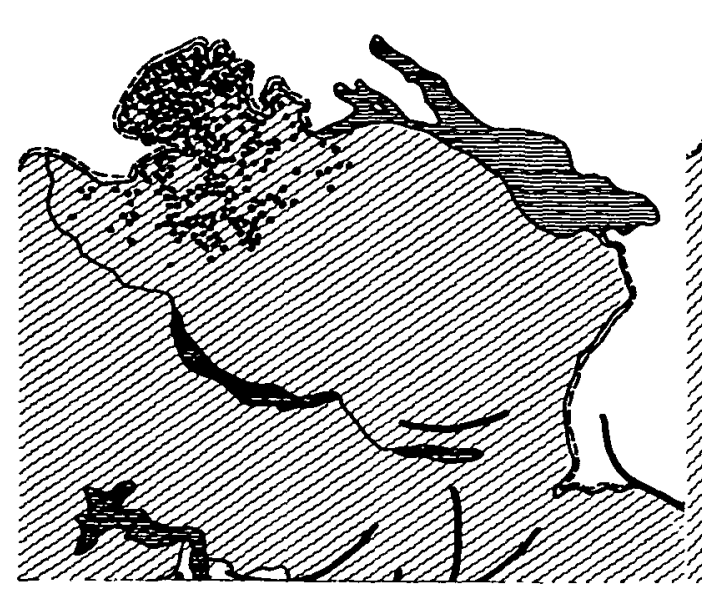

1. April 1968 - 31. March 1969

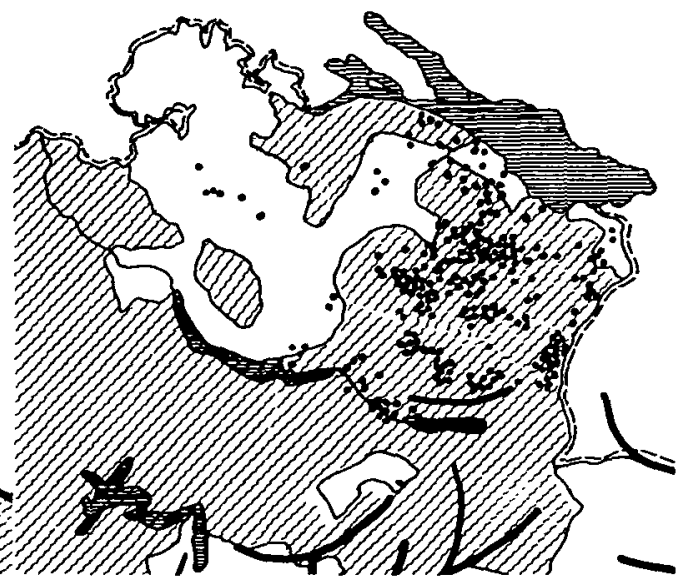

1. April 1971 - 31. March 1972
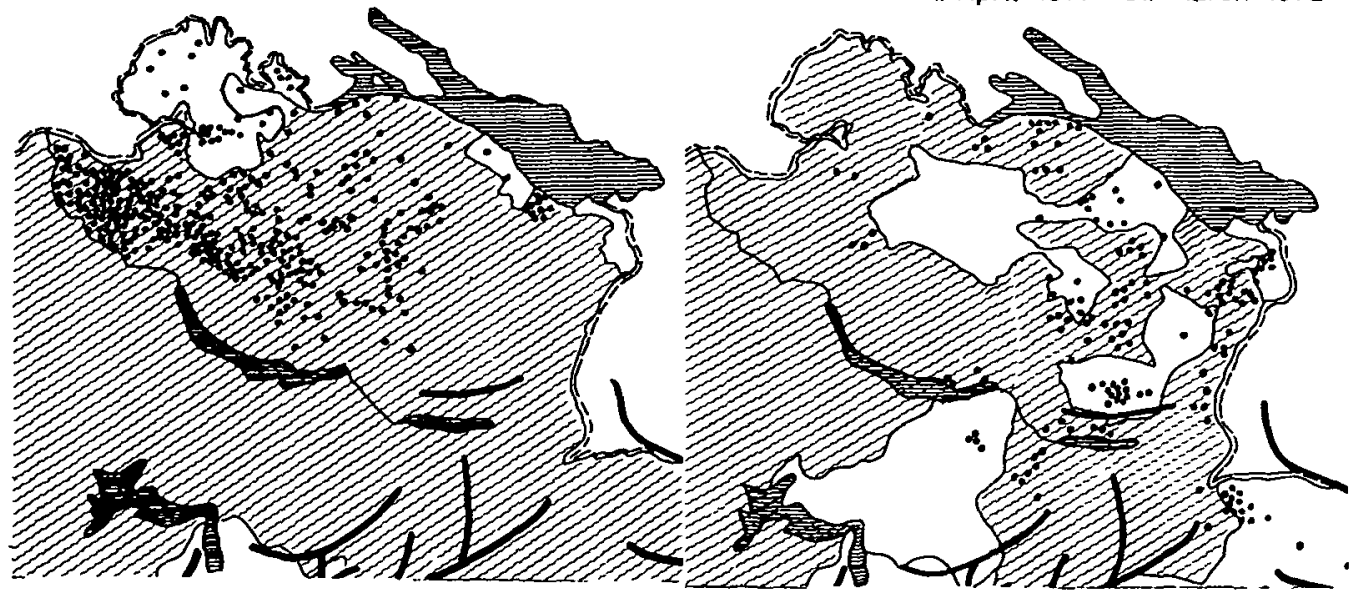

1.April 1969 - 31. March 1970

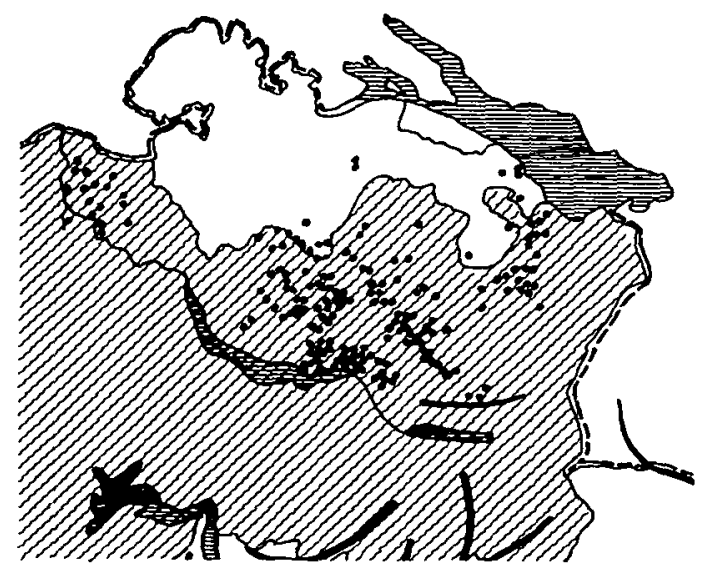

Swiss border (no detailed information on fox density and rabies north of border)

$E$ large lakes

- mountain ranges above $2500 \mathrm{~m}$

foxes killed or found dead:

$\square$ less than 0.3 foxes per sq $\mathrm{km}$

DIJ more than 0.3 foxes per sq $\mathrm{km}$

is individual rabies infected foxes

$\begin{array}{rrrrr}0 & 10 & 20 \quad 30 \quad 40 \quad 50 & \mathrm{~km}^{2}\end{array}$

Figure 6. Frontwave of rabies epizootic moving through northeastern Switzerland, 1967-1972. Reduction to values below and subsequent recovery above the critical level of fox population density as estimated by hunting statistics. 
TABLE 1

Animal species affected by rabies in Switzerland (laboratory results 1967-1978)*

\begin{tabular}{|c|c|c|c|}
\hline Species & $\begin{array}{l}\text { Total no. } \\
\text { examined }\end{array}$ & $\begin{array}{l}\text { No. rabies } \\
\text { positive }\end{array}$ & $\begin{array}{c}\% \text { of all } \\
\text { rabies cases }\end{array}$ \\
\hline \multicolumn{4}{|l|}{ Wild animals } \\
\hline fox (Vulpes vulpes) & 19,054 & 7252 & 76.6 \\
\hline badger (Meles meles) & 1,387 & 397 & 4.2 \\
\hline marten (mostly stone marten) (Martes foina) & 2,847 & 243 & 2.6 \\
\hline polecat (Putorius putorius) & 120 & 6 & 0.06 \\
\hline $\begin{array}{l}\text { stoat (Mustela erminea) and weasel } \\
\quad(M . \text { nivalis) }\end{array}$ & 202 & 0 & 0 \\
\hline wildcat (Felis sylvestris) & 1 & 1 & 0.01 \\
\hline lynx (Felis lynx) & 1 & 0 & 0 \\
\hline roe deer (Capreolus capreolus) & 3,476 & 449 & 4.7 \\
\hline red deer (Cervus elaphus) & 115 & 6 & 0.06 \\
\hline chamois (Rupicapra rupicapra) & 133 & 13 & 0.14 \\
\hline wild boar (Sus scrofa) & 25 & 0 & 0 \\
\hline hare (Lepus europaeus) & 800 & 0 & 0 \\
\hline squirrel (Sciurus vulgaris) & 884 & 0 & 0 \\
\hline marmot (Marmota marmota) & 13 & 1 & 0.01 \\
\hline rat (Rattus norvegicus, $R$. rattus) & 109 & 0 & 0 \\
\hline $\begin{array}{l}\text { mouse and vole (Apodemus, Mus, Microtus, } \\
\text { Arvicola, Clethrionomys) }\end{array}$ & 529 & $(1) \dagger$ & $(0.01)$ \\
\hline dormouse (Glis glis) & 24 & 0 & 0 \\
\hline hedgehog (Erinaceus europaeus) & 140 & 0 & 0 \\
\hline mole (Talpa europea) & 23 & 0 & 0 \\
\hline shrew (Sorex, Crocidura) & 22 & 0 & 0 \\
\hline bat (Chiroptera) & 21 & $\mathbf{0}$ & 0 \\
\hline bird & 195 & $\mathbf{0}$ & 0 \\
\hline Total wild animals & 30,121 & 8368 & 88 \\
\hline \multicolumn{4}{|l|}{ Domestic animals } \\
\hline $\operatorname{dog}$ & 1,207 & 45 & 0.5 \\
\hline cat & 7,851 & 397 & 4.2 \\
\hline cattle & 1,443 & 327 & 3.5 \\
\hline sheep & 1,267 & 256 & 2.7 \\
\hline goat & 191 & 32 & 0.3 \\
\hline swine & 35 & 6 & 0.06 \\
\hline horse & 77 & 23 & 0.2 \\
\hline donkey & 10 & 2 & 0.02 \\
\hline rabbit & 143 & 3 & 0.03 \\
\hline antelope & 2 & 2 & 0.02 \\
\hline others & 134 & 0 & 0 \\
\hline Domestic and zoo animals & 12,360 & 1093 & 12 \\
\hline Total examined & 42,481 & 9461 & 100 \\
\hline
\end{tabular}

* Source: reference 22.

† Parentheses = Virus isolation from salivary gland of one Apodemus sylvaticus after the third blind intracerebral passage in white mice.

other animals become more important after the frontwave of high incidence has moved through an area (21). In Switzerland, during the first six months of an epizootic, foxes constitute 89 per cent of all cases and drop to 66 per cent in the

last six months. On the other hand, badgers and stone martens increase from 4.6-11.7 per cent, roe deer from 3.8-13.4 per cent, and other domestic animals from 2.7-8.8 per cent (table 2).

This relative increase of rabies in ani- 


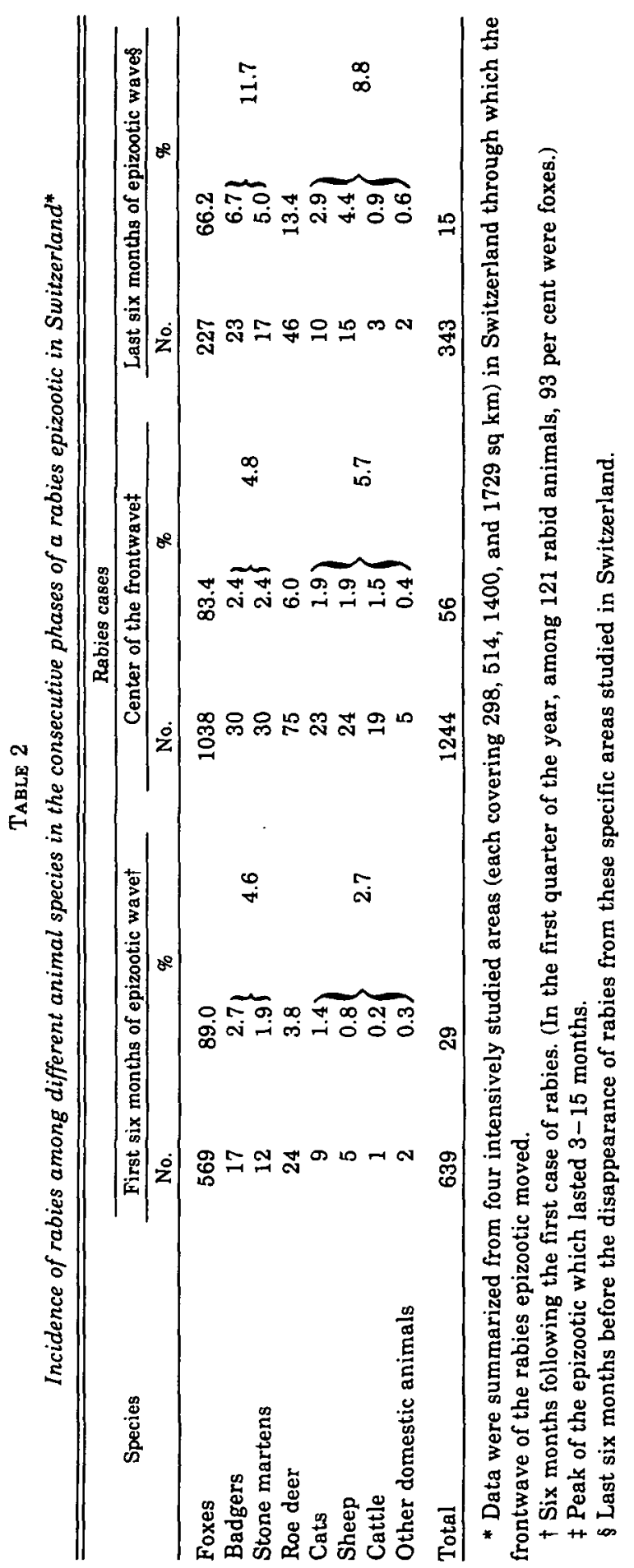


mals other than foxes from the first to the last six months of the epizootic frontwave, before the temporary disappearance of rabies from a given area, applies as much to nontransmitting herbivores as it does to potential transmitters such as mustelids. We think that this is due to late exposure and prolonged incubation periods, rather than to chains of infection among these particular species (with the exception of badgers). The particular events leading to the infection of roe deer (and domestic herbivores) are rarely observed. It is very likely that these animals are bitten while they are defending themselves against the attack of a rabid fox. Roe deer share the habitat of foxes, and their population is of the same order of magnitude as that of sheep, which helps to explain the relative frequency of infection among these deer. Interestingly, rabies cases among domestic cats occur separated in time and location, which makes cat-to-cat transmission also very unlikely. In practice, however, unvaccinated cats belonging to the same household are usually killed if one cat is found to be rabies infected, thus limiting the chance for secondary cases.

The highest incidence of fox rabies observed was in the frontwave of the epizootic, amounting to $0.7-1.8$ rabid foxes per sq $\mathrm{km}$ per year. This represents $30-60$ per cent of all foxes reported killed by hunting, accidents or diseases, which may represent 25-50 per cent of the total fox population.

In all other species a maximum of one or two cases per $20 \mathrm{sq} \mathrm{km}$ are found. Individual animal cases usually occur separated in time and distance, with the exception of badgers, among which local clusters of rabies cases are occasionally found in front of or behind a wave of the epizootic, suggesting short chains of infection among this species. It is of public health importance that virtually no rabies cases are found among rodents (mice, rats and squirrels), hares, insectivores (hedgehogs, shrews), bats or birds (table 1).

The existence of a reservoir of rabies among animals other than foxes often has been postulated (26). However, intensive search, particularly among rodents, has failed to reveal such a reservoir. The characteristics of the epizootic, on the other hand, can be fully explained without necessarily implying that a reservoir exists outside the fox population. In this context it is necessary to discuss the isolation of rabies virus strains from rodents described by Schneider and Schoop (27) and Sodja et al. (28). A common feature of these isolations was that the virus became detectable only after several intracerebral (IC) blind passages in white mice. The virus must have been either in very low titer or masked by interference phenomena (29). Isolation attempts by other workers in Germany $(30,31)$, Switzerland $(4,22)$, and France (32) have been unsuccessful. An average spread of 40 $\mathrm{km}$ per year is impossible by mouse-tomouse transmission, when, for example, a minimal incubation period of six days and an activity range of, say, $100 \mathrm{~m}$ are taken into account.

If fox rabies were an epiphenomenon of an epizootic in an underlying, albeit unknown, reservoir, the incidence of fox rabies would be directly proportional to fox population density, but this is not the case. Below a certain threshold of the fox population, rabies disappears completely, and despite a sizable number of remaining foxes, which gain previous population levels within a few years, rabies may not reappear in parallel incidence. Reinfection, if it does occur, originates from adjoining foci of infection.

\section{RABIES INFECTION IN THE FOX AND OTHER WILD CARNIVORES}

Information on susceptibility, incubation period and duration of clinical symptoms is available virtually only from ex- 


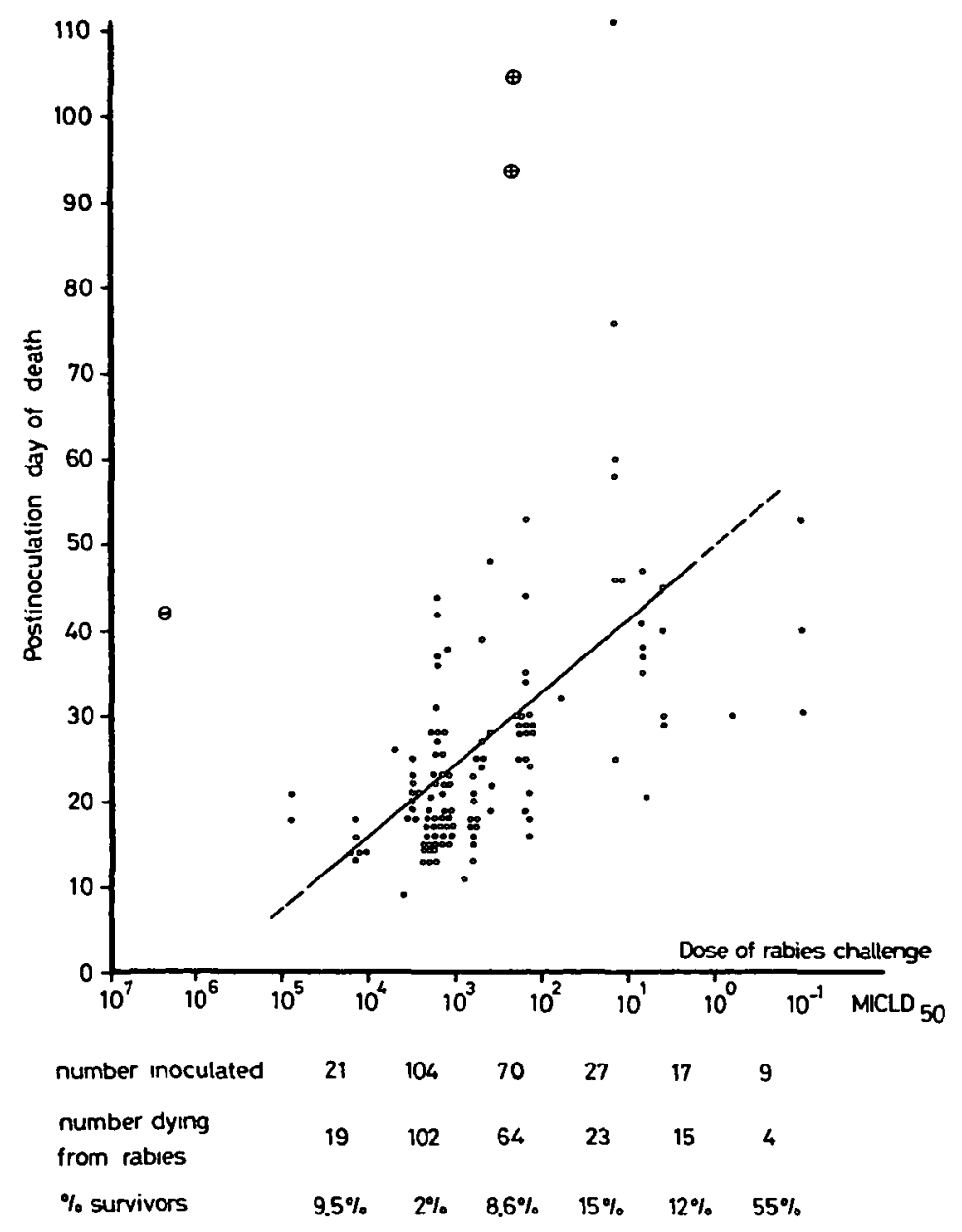

Figure 7. Rabies infection in the fox. Correlation between intramuscular challenge dose and time from inoculation to death. $(\mathrm{O}=$ individual foxes, data from several workers in North America $(3,34,36)$ and Europe (35, 37, 38); $\oplus$ = data from Winkler et al. (39); $\ominus=$ oral exposure (38) challenge virus doses were measured in mouse intracerebral 50 per cent lethal dose $\left(M^{\prime C L D} D_{50}\right)$.)

perimental infections. The susceptibility is markedly dependent on the route of inoculation, e.g., intramuscular (IM), oral, or aerosol inhalation. By the IM route the 50 per cent lethal dose for foxes corresponds to about $0.1-1.0$ mouse intracerebral 50 per cent lethal dose $\left(\right.$ MICLD $\left._{50}\right)$. In figure 7 data from several workers in North America $(3,34,36)$ and Europe (35, 37,38 ) were submitted to regression analysis.

Challenge results obtained with various virulent fox isolates fit into the same pattern with a shortened interval between inoculation and time to death at the higher concentrations of challenge virus. For 67 foxes infected with 1600 MICLD $_{50}$, the mean day of death and SD was $22 \pm 6$ days postinoculation, with a minimum interval to death of 9 days. At concentrations below 100 MICLD $_{50}$ this time interval spanned from $20-111$ days (45 \pm 20 days). Very long incubation periods are not represented since most trials were terminated between 100-150 days postinoculation. No significant 
difference between inoculation into cervical, masseter or gluteus muscles was seen. It is noteworthy that Schmidt and Sikes (34) observed incubation periods of at least $9 \frac{1}{2}, 12$ and 15 months in foxes with naturally acquired infection. Based on intensive surveillance, we think that the periodic reappearance of rabies in certain regions of Switzerland is caused by reinvasion from neighboring areas rather than by extremely long incubation periods in some individual animals (or by an unproven reservoir).

Data not fitting the general pattern seen in figure 7 were, however, obtained by Winkler et al. (39). Only two out of 21 nonimmune foxes died (94 and 105 days) after IM challenge with $250 \mathrm{MICLD}_{50}$ of virulent virus in the quadriceps muscle. It is not clear whether these deaths were due to a reduced virulence of the virus strain used, to the site of inoculation, or to both. Parker and Wilsnack (40) also recorded a delayed time of death with $10^{5}$ MICLD $_{50}$ (median postinoculation day of death 25 , range $21-47$ days) and a longer duration of clinical disease (61 per cent of foxes with clinical disease lasting longer than seven days).

Among the experiments noted in figure $7,2-15$ per cent survivors among the foxes inoculated (at days 100-150) were observed over the whole range of inoculation doses. Among 239 foxes inoculated with 4-80,000 MICLD M0 16 survived. Seven of these foxes were tested for neutralizing antibodies or resistance to challenge, but only two were found to be immune.

Much higher doses of virus appear to be necessary to infect by the oral route. Ramsden and Johnston (41) fed foxes with dead, frozen, infected mice with a total dose of $10^{4.5}-10^{5.4} \mathrm{MICLD}_{50}$ of rabies virus. Two out of seven died of rabies. In addition, one fox developed neutralizing antibodies, but three other survivors succumbed to virulent challenge. In an ex- periment using seven foxes, we instilled a total dose of $10^{6.4} \mathrm{MICLD}_{50}$ of virulent fox virus into the buccal cavity. One fox died from rabies 43 days postinoculation. Among the six survivors, one developed a low titer (1/5) of neutralizing antibody and was resistant to IM challenge (38). However, in experiments done by Blancou et al. (37), only two out of nine foxes survived for more than 400 days, the other seven died between 20-89 days (median 28 days) postinoculation.

We do not know what relative roles are played by the IM (bite) and oral routes of infection under natural conditions. From all evidence available, bite transmission appears to be the most important mode of infection. Concentrations of rabies virus found in brain and salivary glands of most animals found dead appear to be below the oral infection dose $(4,71)$. (Aerosol transmission is not likely to be important in Europe since bat rabies and caves with large populations of bats as they exist in the Americas are unknown.)

From the experimental studies we concluded:

1) Ninety-three per cent of IM infected foxes died (the exceptions were inoculated with the lowest doses).

2) Susceptibility by the oral route is about $10^{5}-10^{6}$ times lower than by IM infection.

3) Among the 7 per cent of foxes surviving IM infection, only about one-third are immunized, e.g., 2 per cent of all infected foxes. Present data are insufficient to judge if a higher proportion may become immune after oral infection. Very large doses of virus would, however, be required.

The evaluation of the immune status of the fox population in the field was hampered by the poor quality of the sera obtained from killed foxes. Interpretation of nonspecific inhibition at lower serum dilutions is difficult to do. However, an estimation can be reached by comparing 


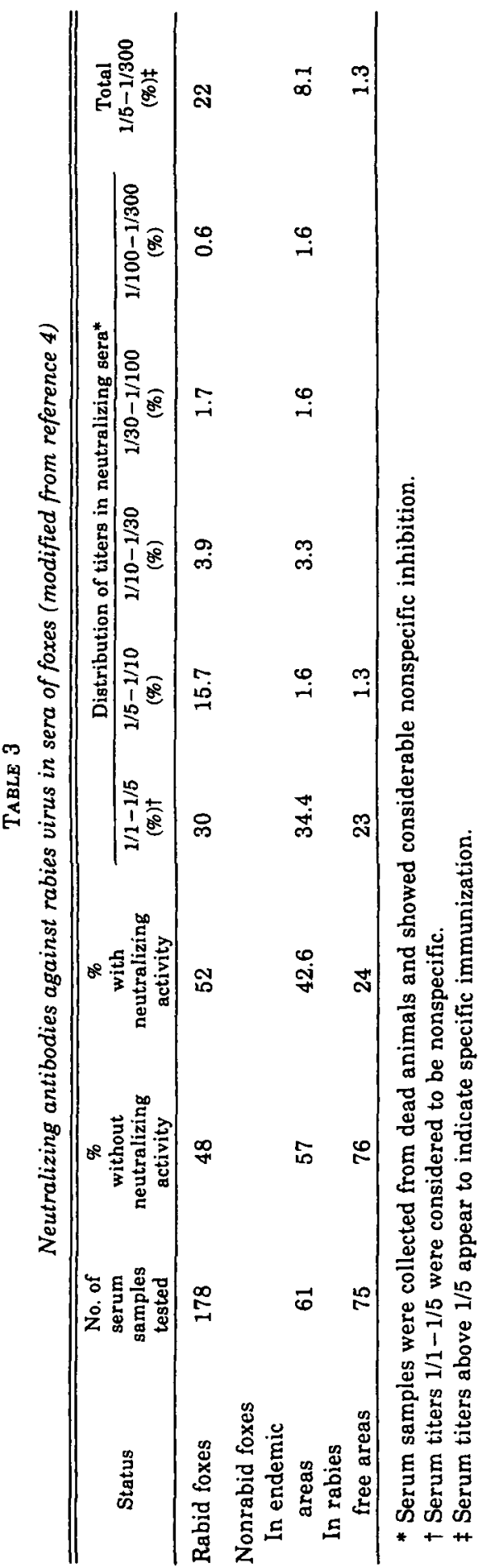

sera obtained from rabies infected and noninfected foxes from endemic areas with sera from foxes collected in areas completely free of rabies. Table 3 summarizes such data, which suggest that not more than 8 per cent of foxes living through the frontwave of the epidemic are actually exposed and immunized against rabies. Similarly, Sikes (3) found four out of 118 foxes with serum-neutralizing antibodies in a rabies endemic area, although Menzel (42) found none with antibodies among 92 nonrabid foxes.

In view of the small population of immune foxes and the simultaneous high population turnover, it is very unlikely that immunity is of epidemiologic importance. On the contrary, the lack of immunity and the rapid recovery of a reduced population appear to be essential factors in maintaining the endemicity of rabies.

A study (4) to detect the presence of rabies virus in the salivary glands was undertaken in foxes, badgers and stone martens collected in the field (table 4). Rabies virus infection of the salivary glands was found in 93 per cent of all foxes dying from rabies, in 83 per cent of rabid badgers and in only 50 per cent of rabid stone martens. On the other hand, there was never an infection of the salivary glands without infection of the central nervous system. These observations would indicate that virus excretion by the salivary glands is linked with classical clinical disease and that no silent shedders occur.

Experimental results indicate that high inoculation doses, e.g., those more than $10^{3.2} \operatorname{MICLD}_{50}(33,38)$ or $10^{3.9}$ MICLD $_{50}$ (40), tend to yield a small proportion of foxes with infected salivary glands, e.g., five out of 23 . Low doses, on the other hand, give rise to a high proportion of foxes with infected salivary glands, e.g., 16 out of 20 foxes at the same time with a relatively long incubation period.

The data from the field showing the 
TABLE 4

Rabies virus infection of the central nervous system and the salivary glands of wild carnivores* (source: reference 4)

\begin{tabular}{|c|c|c|c|c|c|c|c|}
\hline \multirow{2}{*}{$\begin{array}{l}\text { Central } \\
\text { nervous } \\
\text { system } t\end{array}$} & \multirow{2}{*}{$\begin{array}{l}\text { Salivary } \\
\text { glands } \neq\end{array}$} & \multicolumn{2}{|c|}{ Foxes } & \multicolumn{2}{|c|}{ Badgers } & \multicolumn{2}{|c|}{ Stone martens } \\
\hline & & No. & $\%$ & No. & $\%$ & No. & $\%$ \\
\hline \multirow{2}{*}{ Positive } & Positive & 759 & 93 & 68 & 83 & 18 & 50 \\
\hline & Negative & 57 & 7 & 14 & 17 & 18 & 50 \\
\hline Negative & $\begin{array}{l}\text { Positive } \\
\text { Negative }\end{array}$ & $\begin{array}{r}0 \\
635\end{array}$ & $\begin{array}{r}0 \\
100\end{array}$ & $\begin{array}{r}0 \\
270\end{array}$ & $\begin{array}{r}0 \\
100\end{array}$ & $\begin{array}{r}0 \\
417\end{array}$ & $\begin{array}{r}0 \\
100\end{array}$ \\
\hline
\end{tabular}

* Animals were collected within the rabies infected zone and a zone ahead of the frontwave. Conditions under which rabies infected and noninfected animals were collected for examination are comparable to the data in table 5 .

$\dagger$ Diagnosis by immunofluorescence and/or mouse intracerebral inoculation.

¥ Diagnosis by mouse intracerebral inoculation.

very high proportion of infected salivary glands in foxes suggest that the infecting dose may be low and the incubation period correspondingly long under field conditions. The excretion of virus in the saliva is linked with the clinical disease phase. Excretion of virus was, however, observed to occur even three days before death (3).

There is much divergence in the information about the duration of clinical disease. This is mainly because it may be difficult to define the beginning of clinical symptoms. Changes in behavior during the incubation period may have a causal relationship to the infection. If such observations are interpreted as prodromal symptoms, then intermittent clinical disease may last for up to two weeks. Most observers, including ourselves, agree that the clinical phase of the disease appears to last only a few days. A median duration of two days-with a range of $1-14$ days during which time 80 per cent of all inoculated foxes died within three days, and 93 per cent within five days-was seen after IM inoculation $(3,37,38,43)$.

The earliest sign of disease may be the animal's refusal of food for one or two days. After inoculating the fox in the neck muscle, we frequently observed a very fine head tremor, which occasionally increased to heavy shaking within less than 24 hours. During this early phase foxes may or may not be aggressive. Furious forms of the disease are rare, and aggressiveness may become apparent only after provocation. These signs may be influenced very much by the individual experimental foxes. Death is preceded by a paralytic stage with intermittent fits lasting a few hours to a few days.

In our laboratory, recovery from severe clinical disease was noted in only one animal, which had been previously immunized by the oral route with the SAD strain, after challenge with virulent street virus.

Field observations on the clinical behavior shall not be discussed in detail here, since observations of individual animals are often limited to short episodes before they are killed. Among foxes killed because of abnormal behavior (e.g., loss of shyness, paralysis, aggressiveness, etc.) within an endemic area and collected for examination, 86 per cent were actually infected by rabies virus (table 5). On the other hand, Wittmann and Kokles (44) reported that among 105 normal foxes killed during hunting in an endemic area, 10 foxes were found to be rabies infected. The autopsy showed that at least seven animals were probably clinically ill; from further studies involving histopathology and serology, Wittmann and Kokles concluded that latent carriers of rabies virus do not exist. 
FOX RABIES IN EUROPE

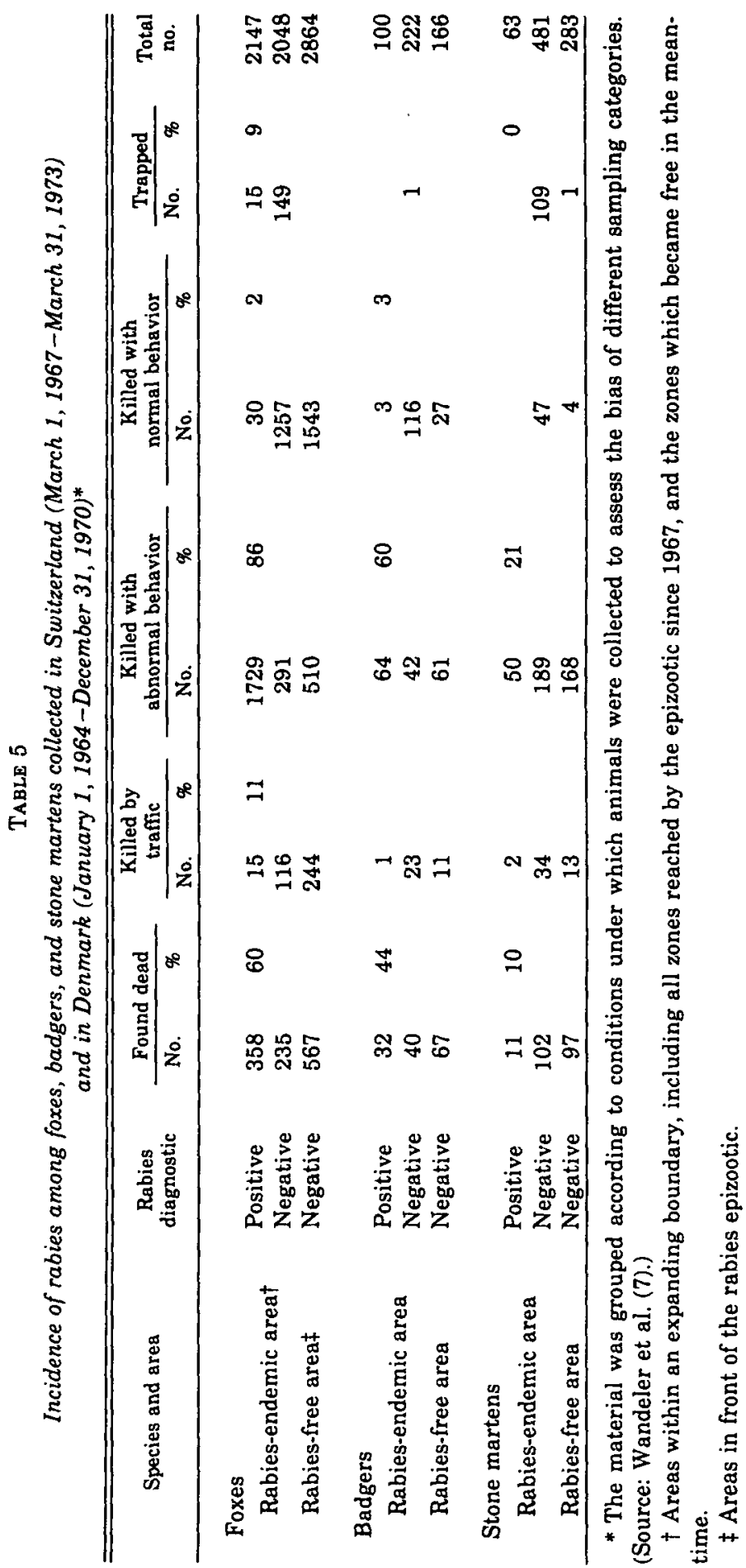


The behavior of rabid foxes was well described by Streiff in 1829 (17):

\begin{abstract}
Already in the year 1825 , the same as in other cantons, strange observations were made, particularly in the lower parts of our canton, on sick foxes, who became very tame and approached, often staggering, houses and barns, where they were easily killed.... In March 1825, during one week, two such diseased foxes came to the barn of $W$. at $N$., where there was a bitch with two puppies. The bitch was fighting with one of these foxes. She came down with rabies in early April, bit her master, her puppies and several other dogs.... Sick foxes were observed in many parts of our canton, showing different stages of the disease, some of them were so stupefied that they could have been killed by any child, but often they were in such a state that they would follow and attack men or animals nearby or even in the midst of villages.
\end{abstract}

\section{FoX ECOLOGY AND BIOLOGY IN RELATION TO RABIES}

Fox population density, linked with population turnover, and social behavior are the main variables which shape the pattern of epizootic fox rabies in Europe. Most of the terrestrial habitats in Central Europe have a high carrying capacity for foxes. Foxes are found in almost every conceivable habitat, from the seashore to alpine meadows above the tree limit. They have even adapted successfully to urban and suburban conditions, reaching quite high population density in many cities in England $(45,46)$. The carrying capacity is certainly limited by food availability. Fox diet may vary a great deal: it may range from earthworms and insects to medium-sized mammals, carrion, and offal, and also berries, fruit and vegetables. Cover and shelter may be another limiting factor. The different kinds of shelter used also influence the success of fox population reduction (47).

Actual population densities are kept below carrying capacities by mortality factors such as human predation, sarcoptic mange, and rabies. In areas with intense fox hunting, but undisturbed by diseases, population densities based on litter counts range between 1.11-1.85 foxes per sq $\mathrm{km}$ after whelping (48). The number of foxes killed per year and unit area indicates much greater variation in population density in other regions. In the absence of precise fox population censuses, hunting records provide valuable information over large areas. Districts with high hunting records tend to have a high incidence of rabies, but in areas with low hunting records, rabies tends to disappear or does not enter (49).

In continental Europe, hunting records indicate that there are $0.8-6$ foxes per sq $\mathrm{km}$ in the flat and hilly land in the absence of rabies or strict control measures. One or two foxes per sq $\mathrm{km}$ can be killed annually for many years without decreasing the density at all.

Smaller fox population densities are found mainly in two areas:

1) Regions with well-organized small game hunting, where foxes are systematically killed by game wardens (23). In these areas the hunting records may not necessarily be much lower, but there is an increased hunting effort throughout the year $(24,50)$.

2) In the alpine region the carrying capacity of biotopes for foxes gradually decreases with increasing altitude. Unfortunately, the hunting effort has the same trend (51). Nevertheless, it is certain that the fox population densities become much lower between $1500-2000 \mathrm{~m}$ above sea level, and above $2000 \mathrm{~m}$ only a few families or individual foxes are present. This is, of course, greatly influenced by snow in winter. Figure 8 shows the hunting records for one area in the Swiss Alps.

In both situations the low density proved to be an obstacle to the spread of rabies. A barrier, as yet not fully understood, prevents rabies from entering the Netherlands, the northwestern part of Belgium, central Czechoslovakia and certain smaller areas within countries affected by the epizootic.

In the alpine region the low fox density at high altitudes had a marked channel- 


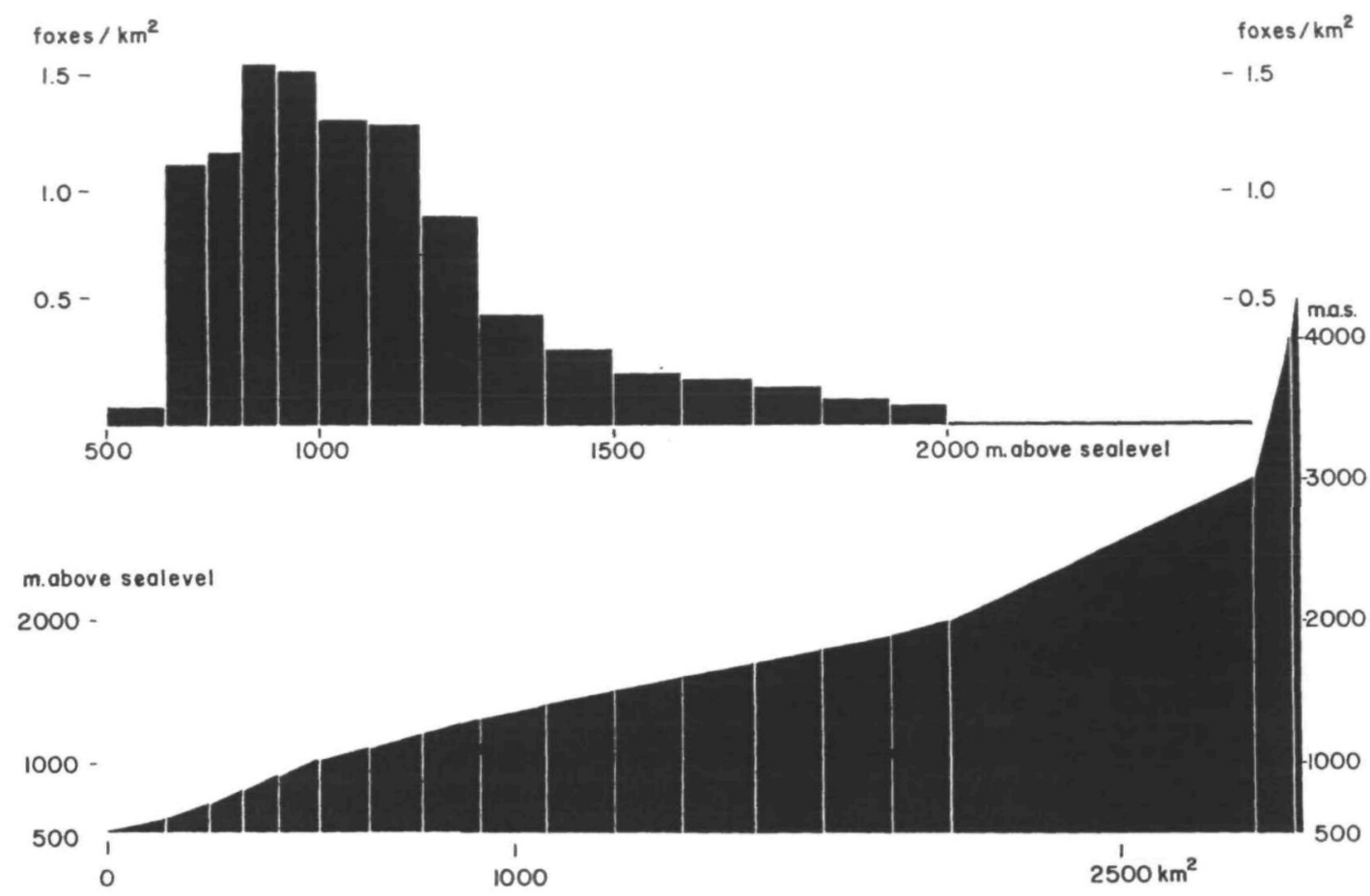

FIgURe 8. Hunting records in the Swiss Alps. Number of foxes shot per sq km by hunters during fall and winter 1978-1979 in the alpine area of the canton of Berne, grouped according to altitude. The low values between $500-600 \mathrm{~m}$ are due to legal hunting restrictions in this densely inhabited area. The reduction in numbers killed at higher altitudes reflects a true trend. The bottom graph represents a surface and altitude profile of the Bernese Alps.

ing effect on the spread of rabies, each valley representing a separate epidemiologic compartment. In Switzerland thus far no alpine pass higher than $2000 \mathrm{~m}$ above sea level has been permanently crossed by the rabies epizootic, despite individual foxes encountered up to $3000 \mathrm{~m}$ above sea level. However, the invasion of northern Italy (South Tirol) from Austria over the Krimmler Pass (2600 m above sea level) demonstrated that these barriers are not absolute (52).

Denmark, linked with continental Europe by a landbridge only $60 \mathrm{~km}$ wide, successfully stopped the rabies invasion in 1964-1965 and 1969-1970 by drastic reduction of the fox population (53). A third outbreak starting in 1977 has not yet been brought under control. Similar, but less spectacular results have been obtained in other parts of Europe. The most efficient method used was the gassing of fox dens during the whelping season. An analysis of data from West Germany by Moegle and Dietz (8) and comparison with other areas in Central Europe have shown that the critical fox population density below which rabies tends to disappear is reflected by an annual kill through hunting of $0.3-0.4(0.315)$ foxes per sq km (figure 4). It is noteworthy, however, that hunting records are as much dependent on hunting habits and intensity as on fox population density.

After the frontwave of the epizootic has passed, there is a very dramatic drop in numbers recorded, particularly when high population densities are present and when aided by systematic gassing of fox dens. We believe that this indicates a real drop in population size (figure 5).

In the series of maps depicting the first 


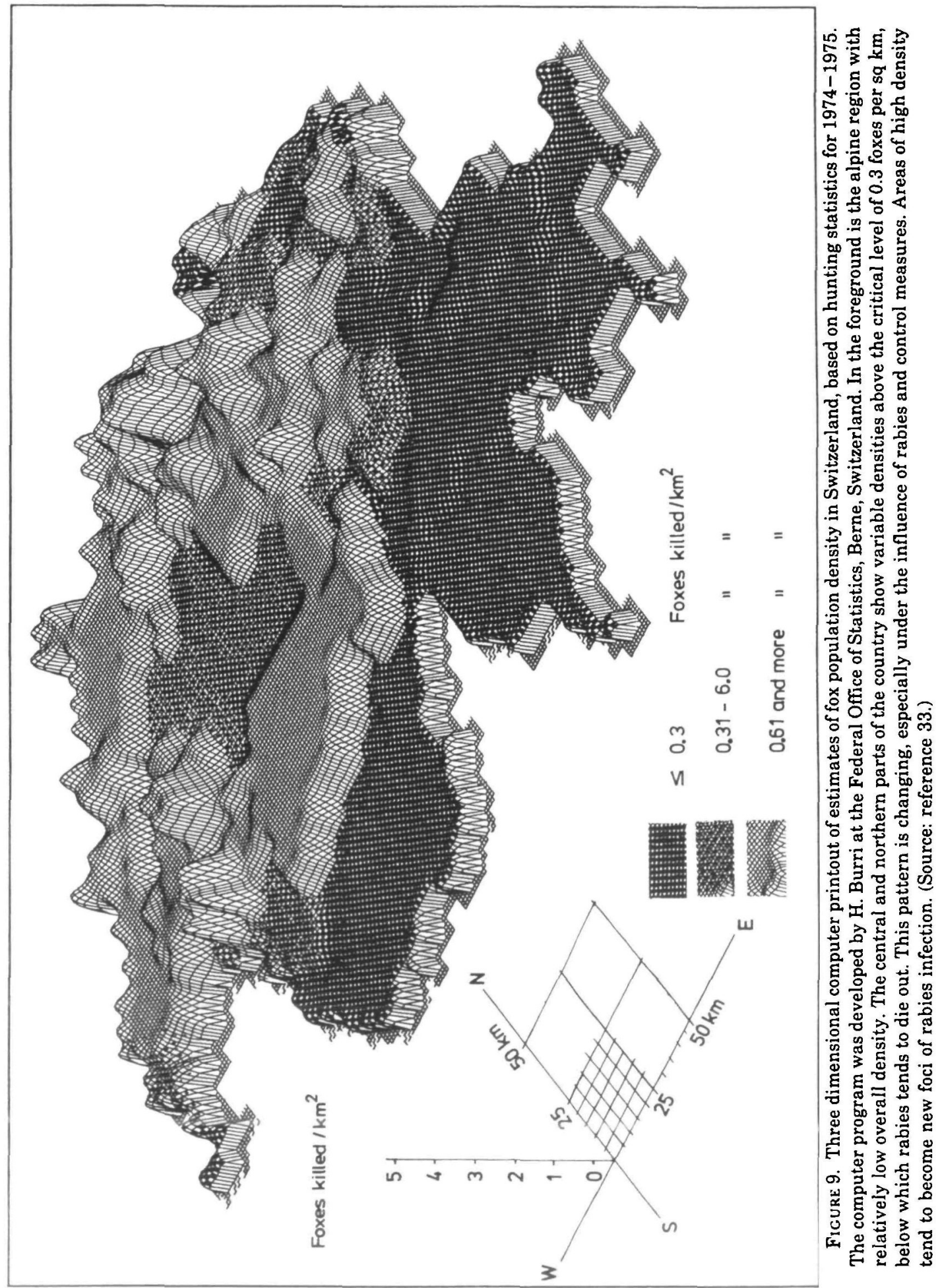


years of the rabies epizootic in Switzerland (figure 6), we show how the frontwave of rabies is followed by a zone of reduced fox population density and a gradual recovery. Population density remains low for a few years, during which period rabies is absent from the area. To simplify the picture, we have included only two levels of hunting records in the maps, i.e., below or above 0.3 foxes per sq $\mathrm{km}$. Actually, the situation is, of course, much more complex.

Reduction and recovery are not similar in all areas. The result is a mosaic of rather small districts behind the frontwave which harbor fox populations above or below the critical level (figure 9) (33). Their population density, size and distance from the frontwave or from other foci determine their chances to get reinfected by rabies. Under appropriate condi- tions, new epidemic waves may start from the scattered foci of rabies behind the initial frontwave. If reporting is insufficient, this may look as if isolated cases of rabies or small foci may reappear without connection to other foci. We do not think that this is so; rabies does not go "underground" between major outbreaks, but reinfection occurs from adjacent infected areas.

The above-mentioned recovery of a reduced population depends on reproduction and perhaps on reduced hunting pressure due to fewer foxes found and the threat of rabies immediately after an epizootic. In Central European areas most vixens become pregnant during mating season in January and February. Fetal implantations average 5.15 per uterus. Puppies observed in the den average 4.67 per litter (47). The animals are born in spring and

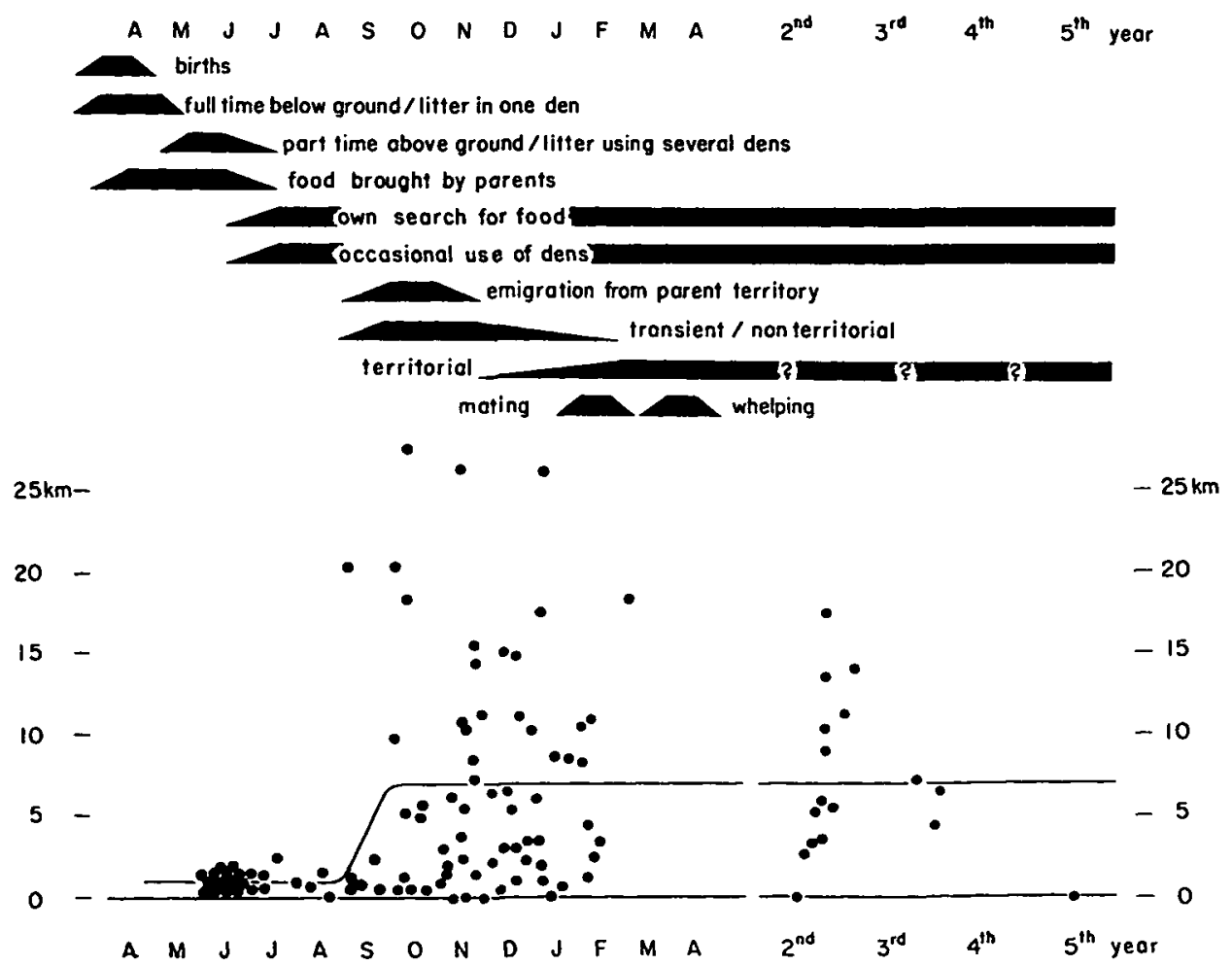

Figure 10. Top: Schematic representation of some aspects of the life history and annual cycle of fox biology (April-April). Bottom: Distance between den of initial capture and place of recovery at different time intervals after ear-tagging fox puppies in May and June. The puppies were marked and released into their den immediately after capture (April-April). $(-$ individual foxes at time and distance of recovery.) 
reach maturity in the following winter, the young females showing a reproductive performance similar to the older ones. Data on reproduction may look very different when analyzed in areas with lower hunting pressure $(54,55)$ or with great variation in food supply (56). In Central Europe the two- to threefold annual increase in population in spring is reduced to an unknown extent by juvenile mortality, hunting, accidents, and diseases, especially rabies, in certain areas. The result is a prewhelping population of low density.

The data on reproduction and mortality suggest a rapid population turnover. This is also indicated by the recognized 70 per cent of juveniles among the total healthy foxes killed by hunters in the fall. Rabid foxes collected in the same areas are significantly older and usually are about 50 per cent juveniles. Both samples most likely fail to reflect the true age structure of fox populations (57).

Many authors $(7,58,59)$ have pointed out that the social behavior of foxes and the social structure of their populations are of crucial importance for the bitetransmitted disease. Social behavior follows the annual reproduction and mortality cycle (figure 10). In adult foxes a male-female pair seasonally shares a home range with their young of the year. The recorded home ranges are between $1 / 4-10 \mathrm{sq} \mathrm{km}$. While many authors (59-61) have reported that foxes observe territories with clearcut borders, others $(54,62)$ have indicated that foxes travel throughout nonexclusive and overlapping home ranges. Juvenile foxes, aged six months, may leave the family territory and disperse over quite a large area (figure 10). The median distance traveled by juvenile foxes in fall in Switzerland is 5.2 km. A significant number of young females remain in or near the parent territory, while most males emigrate (63, $64)$. The juveniles represent a large proportion of the population and also make up a significant percentage of nonterritorial animals in the fall. In areas with moderate population density or with high turnover, most of the young animals participate in breeding in midwinter and establish their own territories. In regions with high fox density the young surplus females become part of a territorial fox family, but do not reproduce. The surplus males remain itinerant and nonterritorial (55). Interestingly, rabies incidence (figure 11) and spread are at a minimum (21) in April, May and June, immediately after the whelping season, when the total fox population has reached a maximum. This is paralleled by the observation that only a small proportion of very young foxes are found rabid, reaching the adult level of infection only during winter (figure $12 \mathrm{a}, \mathrm{b}$ ). It is difficult to weigh to what degree the samples are biased by high juvenile mortality from other causes. However, the same trend is apparent if we compare absolute numbers of rabies infected juvenile foxes versus adult foxes

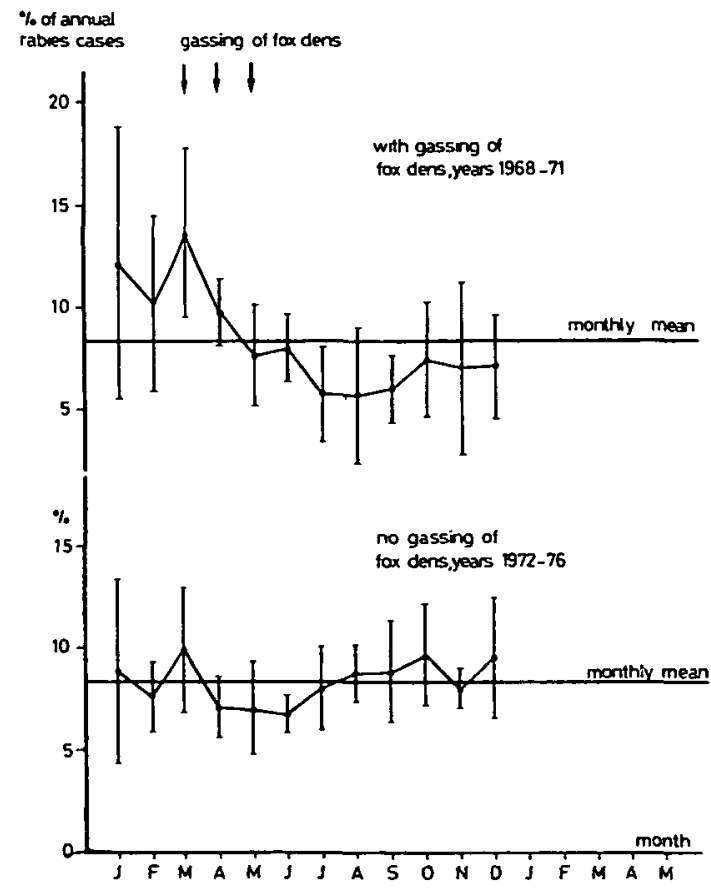

Figure 11. Monthly fluctuation of rabies incidence. 

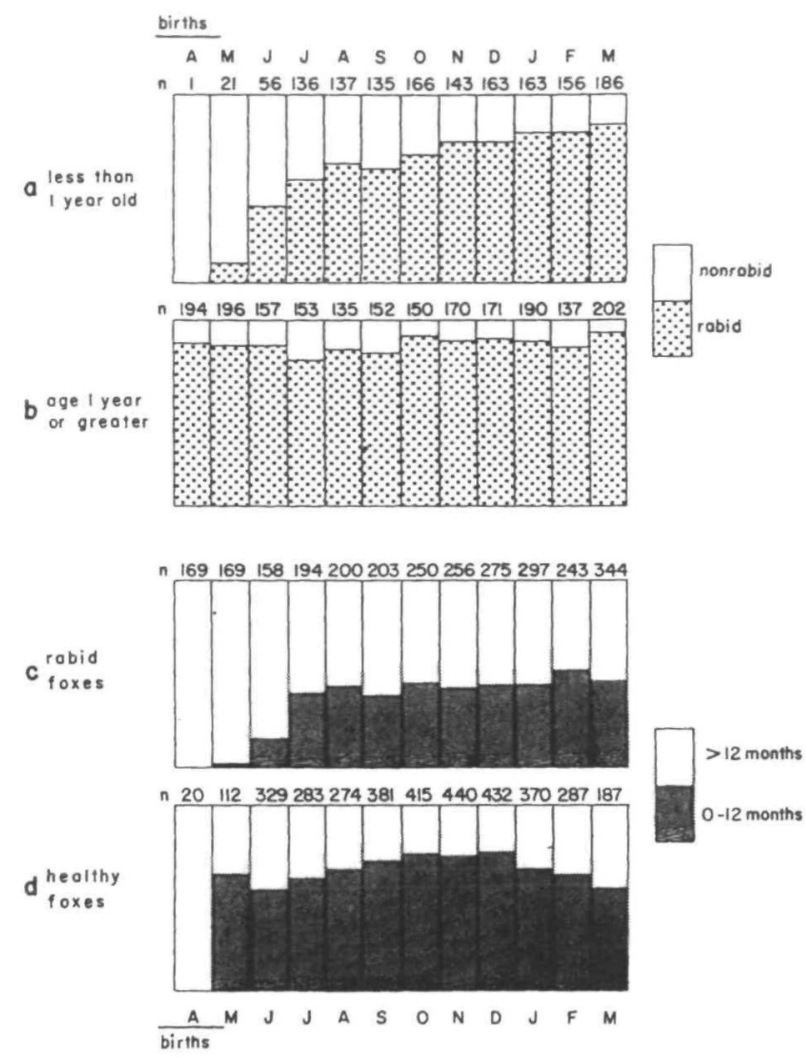

Figure 12. Involvement of different age groups in the rabies epizootic (April-March)-a and b: Ratio of rabid to nonrabid animals in monthly samples of foxes found dead or killed because of abnormal behavior; $c$ : Ratio of foxes younger than 12 months to older ones in monthly samples of rabid foxes; d: Ratio of foxes younger than 12 months to older ones in monthly samples of healthy foxes shot by hunters.

(figure $12 \mathrm{c}, \mathrm{d}$ ). This feature is certainly caused by the different social behavior of juveniles and adults, and not by differences in susceptibility: Adults within their territories attack intruders, while juveniles avoid outsiders. It should be remembered that for rabies transmission to occur the participation of a sick fox and a healthy one is required. An aggressive sick fox may bite a healthy individual only if the latter responds to the challenge. But there are numerous other possibilities for infectious contacts in addition to this one.

\section{IMPACT OF FOX RABIES ON DOMESTIC ANIMALS AND HUMANS}

The overall incidence of rabies in domestic animals in the fox epizootic is relatively low, involving only 5-10 per cent of all registered rabies cases. Two groups of animals are essentially involved: 1) cattle and sheep on pasture, and 2) dogs and cats. Rabies in other species of domestic animals is very rare (table 1). All these cases occur sporadically and are secondary to fox rabies.

Multiple cases may occur in herds of cattle or sheep, suggesting a common source of infection. A higher incidence of cases is encountered if rabies invades an area where large herds are grazing. Usually, no special prophylactic measures are taken, but in certain regions, the vaccination of cattle against rabies has become economically advantageous $(22,65)$. Often a combined foot-and-mouth disease and rabies vaccine is used. 
Two human cases have been traced back to exposure to rabid cattle in the last 30 years $(66,67)$. In one instance a veterinarian died six months after having explored with bare arms the pharynx of a rabid cow.

Surprisingly, under given conditions, rabies in dogs and cats has no tendency to evolve into cycles of infection independent of fox rabies. It is not known whether this is due to particular characteristics of the fox rabies virus strains involved or to other reasons. Dogs are subject to registration and licensing in all areas thus far reached by fox rabies. Dog vaccination is forbidden in some countries and compulsory in others, a circumstance which has greatly influenced the incidence of rabies in dogs.

In Germany, where vaccination is not compulsory, cases of dog rabies represent 2-9 per cent of all infected animals (15, 71). In Switzerland, where vaccination is compulsory in all endemic areas, only 45 (or 0.5 per cent) rabid dogs were diagnosed in 12 years of a total of 9400 rabid animals (22).

Cat vaccination is done on a random, voluntary basis in most regions. Cats are, however, second or third in their importance after dogs and foxes as a potential link between wildlife rabies and humans. Rabid cats are usually aggressive; unprovoked attacks with biting or scratching of people or other animals were observed in 80 per cent of these animals. Certain administrative regions in Switzerland are attempting systematic programs of vaccination and control of stray cats.

Rabies is found in most other species of domestic animals and in zoo animals, mostly ruminants, but the absolute numbers are relatively small. However, human exposure to these species may lead to treatment of large numbers of people.

Wachendörfer (19) has compiled data from the WHO European region for 1972-1976, including not only the re-

TABle 6

Number of rabies cases reported in relation to prophylactic treatment in humans, WHO European region, $1972-1976^{*}$

\begin{tabular}{|c|c|c|c|c|c|c|}
\hline \multirow{3}{*}{ Rabies ecologyt } & \multicolumn{4}{|c|}{ Rabies cases reported } & \multirow{2}{*}{\multicolumn{2}{|c|}{ Persons treated after exposure }} \\
\hline & \multicolumn{2}{|c|}{ Animals } & \multicolumn{2}{|c|}{ Humans } & & \\
\hline & No. & Ratio & No. & Ratio & No. & Ratio \\
\hline Sylvatic rabies & 63,672 & 0.8 & $19+$ & 0.03 & $82,074 \S$ & 0.08 \\
\hline Canine rabies & 8,442 & 0.1 & $369^{* *}$ & 0.6 & 431,514 & 0.4 \\
\hline $\begin{array}{l}\text { Canine rabies together } \\
\text { with local foci of } \\
\text { wildlife rabies }\end{array}$ & 10,150 & 0.1 & $229+t$ & 0.4 & 488,182 & 0.5 \\
\hline Free of rabies & $1^{\mathrm{lt}}$ & & 47 & 0.01 & $4,373^{*}$ & 0.004 \\
\hline Total & 82,265 & 1.0 & 621 & 1.0 & $1,006,143$ & 1.0 \\
\hline
\end{tabular}

* Modified from Wachendörfer (19).

† Sylvatic rabies cases reported in Poland, the German Democratic Republic, Hungary, the Federal Republic of Germany, Belgium, Luxembourg, France, Switzerland, Austria, Czechoslovakia, Italy; canine rabies cases reported in Turkey, Morocco, Algeria; canine rabies together with local foci of wildlife rabies reported in Yugoslavia, Rumania, Soviet Union (European region); countries free of rabies include Great Britain, Ireland, Norway, Sweden, Finland, Spain, Portugal, Bulgaria.

$\ddagger$ Number of human cases: Czechoslovakia, one; the Federal Republic of Germany, three; Poland, five.

Ten human cases were imported: the Federal Republic of Germany, four; France, six.

$\S$ Includes preexposure treatment in 1198 individuals.

"Bulgaria.

I Number of human cases imported: Sweden, one; United Kingdom, three.

- Includes preexposure treatment in 2363 individuals.

** Number of human cases: Algeria, 116; Morocco, 22; Spain, one; Turkey, 230.

t† Number of human cases: Soviet Union, 200; Yugoslavia, 29. 
FOX RABIES IN EUROPE

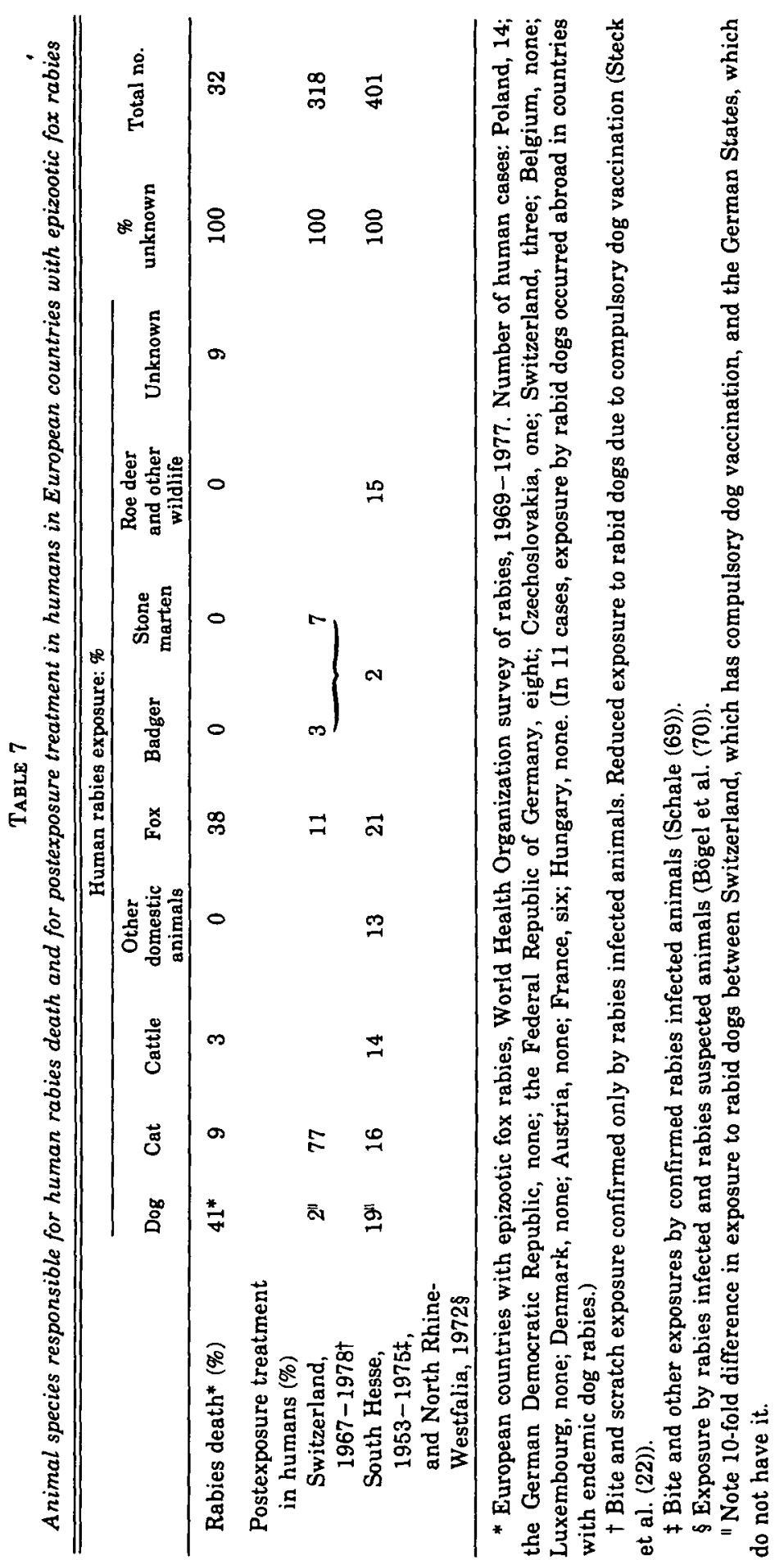


gions affected by fox or sylvatic rabies, but also those regions of eastern and southeastern Europe where dog rabies is still prevalent (table 6). This table illustrates the fact that canine rabies has a much greater impact on human health than sylvatic rabies. Seventy-seven per cent of all animal cases are in sylvatic species, but these are responsible for only 8 per cent of human treatments and only 1-2 per cent of all human cases. Among the 32 cases of human rabies (table 7) which occurred in 1969-1977 in the European countries affected by epizootic fox rabies alone, 13 were caused by dogs, but 11 of these cases were imported (i.e., the exposure to rabid dogs occurred abroad in a country where endemic canine rabies persists; the people became ill after their return to another country, some of which are considered to be rabies free). The European situation as a whole could be dramatically improved if dog control and vaccination programs were carried out in all areas with endemic dog rabies.

In the European countries with endemic fox rabies, close to $\mathbf{4 0}$ per cent of fatal human cases were, however, caused by rabid foxes. Through its direct and indirect effects, fox rabies is of public health and economic importance (68). In these same areas over 16,000 people have to undergo postexposure treatment each year. There is certainly some, but no excessive overtreatment. The animal exposure responsible for postexposure treatment in several fox rabies endemic areas is listed in table 6 . The majority of treatments stem from exposure to infected domestic animals. However, up to 23 per cent of bite exposures are caused by rabid wild carnivores, and an additional 9-19 per cent are caused by other wildlife, particularly roe deer. This illustrates that even if rabies in domestic animals were controlled, a definite hazard from wildlife rabies would still exist.

\section{REFERENCES}

1. Wiktor TJ, Koprowski H: Monoclonal antibodies against rabies virus produced by somatic cell hybridization: Detection of antigenic variants. Proc Natl Acad Sci USA 75:3938-3942, 1978

2. Murphy FA: Rabies pathogenesis, brief review. Arch Virol 54:279-297, 1977

3. Sikes RK: Pathogenesis of rabies in wildlife. I. Comparative effect of varying doses of rabies inoculated into foxes and skunks. Am J Vet Res 23:1041-1047, 1962

4. Wandeler A, Wachendörfer G, Förster U, et al: Rabies in wild carnivores in Central Europe. II Virological and serological examinations. Zentralbl Veterinaermed (B) 21:757-764, 1974

5. Dean DJ: Practical problems in rabies control panel discussion. Public Health Rep 70:564569,1955

6. Jensen B, Müller J: Density of fox populations, with special reference to methodology and significance for rabies prevalence. WHO/FAO Coordinated Research Programme on Wildlife Rabies in Europe, 2nd informal discussion. Munich, July 14-16, 1970

7. Wandeler A, Wachendörfer G, Förster $U$, et al: Rabies in wild carnivores in Central Europe. I. Epidemiological studies. Zentralbl Veterinaermed (B) 21:735 - 756, 1974

8. Moegle H, Dietz K: Personal communication, 1979

9. Toma B, Andral L: Epidemiology of fox rabies. Adv Virus Res 21:1-36, 1977

10. Seroka D: WHO Conference on Surveillance and Control of Rabies. Frankfurth/Main, November $15-19,1977$

11. WHO: Rabies in Poland 1940-1977. Weekly Epidemiologic Record, No 13, March 30, 1979

12. Schoop G: Ueber den derzeitigen Tollwutseuchenzug. Zschr Hyg u Infekt Krkh 138: 415-426, 1954

13. Kauker E: Die Tollwut in Mitteleuropa von 1953 bis 1966. Sitzungsberichte der Heidelberger Akademie der Wissenschaften Mathemat.-naturwissenschaftliche Klasse. Abhandlung 4. Berlin, Heidelberg, New York, Springer Verlag, 1966

14. Kauker E: Vorkommen und Verbreitung der Tollwut in Europa von 1966-1974. Sitzungsberichte der Heidelberger Akadamie der Wissenschaften. Mathemat.-naturwissenschaftliche Klasse. Abhandlung 2. Berlin, Heidelberg, New York, Springer Verlag, 1975

15. Eichwald C, Pitzschke H: Die Tollwut bei Mensch und Tier. VEB Gustav Fischer Verlag Jena, 1967

16. Steck F, Addy P, Schipper E, et al: Der bisherige Verlauf des Tollwutseuchenzuges in der Schweiz. Schweiz Arch Tierheilkd 110:597 616,1968

17. Streiff MD: Ueber das Erscheinen kranker Füchse im Canton Glarus und die durch den Biss solcher Tiere verursachte Wuthkrankheit. Arch Tierheilkd 4:140-149, 1829

18. Köchlin JR: Ueber die in unseren Zeiten unter 
den Füchsen herrschende Krankheit und die Natur und Ursachen der Wutkrankheit überhaupt. Zürich, Orell Füssli, 1835

19. Wachendörfer G: Rabies in the European re gion. Annex II to WHO Report on the Confer ence on Surveillance and Control of Rabies, Frankfurt, November 15-19, 1977

20. WHO Collaborating Center for Rabies Surveil lance and Research. Tuebingen, Federal Republic of Germany. Rabies Bulletin Europe, Volume 3, 1979

21. Bögel K, Moegle H, Knorpp F, et al: Character istics of the spread of a wildlife rabies epidemic in Europe. Bull WHO 54:433-447, 1976

22. Steck F, Wandeler A, Nydegger B, et al: Tollwut in der Schweiz 1967-1978. Schweiz Arch Tierheilkd (in press)

23. Gessler M: Grenzen der Tollwutausbreitung in Nordrhein Westfalen. WHO Consultations on Natural Barriers of Wildlife Rabies in Europe. Berne, October 25-27, 1979

24. Rosicky B, Rödl P: Wildlife rabies in Europe-an anthropogenic barrier. WHO Consultations on Natural Barriers of Wildlife Rabies in Europe. Berne, October 25-27, 1979

25. Steck F: Betrachtungen über die Biologie der Tollwut. Rev Suisse Zool 75:665-681, 1968

26. Nikolitsch M: Die Tollwut. Abhandlung 6 . Stuttgart, Gustav Fischer Verlag, 1961, p 40

27. Schneider LG, Schoop U: Pathogenesis of rabies and rabies-like viruses. Ann Inst Pasteur $123: 469-476,1972$

28. Sodja J, Lim D, Matouch O: Isolation of rabies like virus from small wild rodents. J Hyg Epidemiol Microbiol Immunol 15:271-277, 1971

29. Clark HF: Factors affecting the virulence for mice of fixed rabies viruses. In Bachmann PA (ed): WHO Munich Symposia on Microbiology "Mechanisms of Viral Pathogenesis and Virulence," 1979

30. Wachendörfer G: Grundsätzliches zur Epidemiologie und Bekämpfung der silvatischen Tollwut in der BRD. Prakt Tierarzt 55:685690,1974

31. Förster U, Wachendörfer G, Krekel H: Untersuchungen zum Nachweis von Tollwutvirus in Nagern und Insektivoren-ein Beitrag zur Epidemiologie der Tollwut. Berl Muench Tieraerztl Wochenschr 90:335-337, 1977

32. Hannoun C: Report of the informal discussion on the WHO/FAO Coordinated Research Programme on Wildlife Rabies in Europe. Nancy, July 3-5, 1972

33. Burri H: Unpublished computer printout program data on fox density, from the Swiss Federal Statistical Center, Berne, Switzerland, 1980

34. Schmidt RC, Sikes RK: Immunization of foxes with inactivated virus rabies vaccine. Am $J$ Vet Res 29:1843-1847, 1968

35. Atanasiu P, Guillon JC, Vallée A: Contribution à l'étude de la rage expérimentale du renard. Ann Inst Pasteur 119:260-269, 1970
36. Baer GM, Abelseth MK, Debbie JG: Oral vaccination of foxes against rabies. Am J Epidemiol 93:487-490, 1971

37. Blancou J, Aubert MFA, Andral L, et al: Rage expérimentale du renard roux (Vulpes vulpes) 1. Sensibilité selon la voie d'infection et la dose infectante. Rev Méd Vet 130:1001-1015, 1979

38. Steck F, Wandeler A, Häfliger U, et al: Unpublished results on 80 foxes, 1976-1979

39. Winkler WG, McLean RG, Cowart JC: Vaccination of foxes against rabies using ingested baits. $J$ Wildl Dis 11:382-388, 1975

40. Parker RL, Wilsnack RE: Pathogenesis of skunk rabies virus: Quantitation in skunks and foxes. Am J Vet Res 27:33-38, 1966

41. Ramsden RO, Johnston DH: Studies on the oral infectivity of rabies virus in carnivora. $J$ Wildl Dis 11:318-324, 1975

42. Menzel H: Untersuchungen zum Vorkommen neutralisierender Antikörper bei wildlebenden Tieren gegenüber dem Tollwutvirus. Vet Med Inaugural-Dissertation Giessen, 1973

43. Gierloff BCH: Rabies in inoculated dogs and foxes (in Danish). Nord Vet Med 19:145-162, 1967

44. Wittmann W, Kokles R: Weitere Untersuchungen zur Frage der latenten Tollwutinfektion bei Füchsen. Arch Exp Veterinaermed 21:165-173, 1967

45. Harris S: Distribution, habitat utilization and age structure of a suburban fox (Vulpes vulpes) population. Mammal Rev 7:25-39, 1977

46. Page RJC: Studies on the urban fox population in London. WHO Consultation on Natural Barriers of Wildlife Rabies in Europe. Berne, October 25-27, 1979

47. Wandeler A, Müller J, Wachendörfer $\mathbf{G}$, et al: Rabies in wild carnivores in Central Europe. III. Ecology and biology of the fox in relation to control operations. Zentralbl Veterinaermed (B) 21:765-773, 1974

48. Wandeler A: Einige Daten über den bernischen Fuchsbestand. Rev Suisse Zool 75:1071-1075, 1968

49. Moegle H, Knorpp F, Bögel K: Einfluss der Begasung der Fuchsbaue auf die Fuchsdichte und die Wildtollwut in Baden-Württemberg. Berl Muench Tiernaerztl Wochenschr 84:437-441, 1971

50. Moegle H: Orientierende Untersuchungen über ein bisher tollwutfreies Gebiet am Oberrhein. WHO Consultations on Natural Barriers of Wildlife Rabies in Europe. Berne, October 25-27, 1979

51. Wandeler A: Fox population and fox hunting in the canton Berne. WHO Consultations on Natural Barriers of Wildlife Rabies in Europe. Berne, October 25-27, 1979

52. Irsara A: Presenza ed importanza della rabbia in Italia. Selezione Veterinaria 14:78-86, 1978

53. Müller J: The effect of fox reduction on the occurrence of rabies. Observations from two outbreaks of rabies in Denmark. Bull Off Int Epiz 75:763-776, 197 
54. Lloyd HE: Fox, Vulpes vulpes. In Corbert GB, Southern HN (eds): The Handbook of British Mammals. Oxford, Blackwell Scientific Publications, 1977, pp 311-320

55. Macdonald DW: Social factors affecting reproductive success in the red fox, Vulpes vulpes. In Zimen E (ed): The Red Fox: Behaviour and Ecology. Proceedings of the Symposium on Fox Biology. Saarbrücken, 1979. The Hague, W Junk, 1980

56. Englund J: Some aspects of reproduction and mortality rates in Swedish foxes (Vulpes vulpes) 1961-63 and 1966-69. Viltrevy 8:2-82, 1970

57. Wandeler A: Altersbestimmung bei Füchsen. Rev Suisse Zool 83:956-963, 1976

58. Kauker E, Zettl K: Die Oekologie des Rotfuchses und ihre Beziehung zur Tollwut. DTW 67:463-467, 1960

59. Macdonald DW: The behavioral ecology of the red fox. In Kaplan C (ed): Rabies-The facts. Oxford, Oxford University Press, 1977, pp $70-90$

60. Sargeant AB: Red fox spatial characteristics in relation to waterfowl predation. J Wildl Mgmt 36:225-236, 1972

61. Niewold FJJ: Irregular movements of the red fox (Vulpes vulpes) determined by radio tracking. Trans Int Congr Game Biol 2:331-337, 1974

62. Harris S: Home ranges and patterns of distribution of foxes (Vulpes vulpes) in an urban area, as revealed by radio tracking. In Amlaner $\mathrm{CJ}$, Macdonald DW (eds): A Handbook on Biotelemetry and Radio Tracking. Oxford, Pergamon Press, 1980, pp 685-690

63. Jensen B: Movements of the red fox (Vulpes vulpes $\mathrm{L}$ ) in Denmark investigated by marking and recovery. Dan Rev Game Biol 8:1-20, 1973

64. Storm GL, Andrews RD, Phillips RL, et al: Morphology, reproduction, dispersal and mortality of midwestern red fox populations. Wildl Monogr 49:1-82, 1976

65. Andral L, Toma B: Etude de l'épidémiologie de la rage vulpine en France (1968-1973). Cah Méd Vét 42:203-214, 1973

66. Sinnecker H, Apitzsch L, Demski G, et al: Die Entwicklung der Tollwut in der DDR 1953 bis 1970. Z Gesamte Hyg 21:39-45, 1975

67. Gräni R, Wandeler A, Steck F, et al: Tollwut bei einem Tierarzt. Schweiz Med Wochenschr 108:593-597, 1978

68. Kahl W, Quander J, Posch J, et al: Cost analysis of wild life rabies and its control in Europe. Zentralbl Bakteriol (Orig A) 240:279-296, 1978

69. Schale FW: Studie zur Epidemiologie der Tollwut. Vet-Med-Inaugural-Dissertation Giessen, 1975

70. Bögel K, Posch J, Quander J, et al: Antirabies treatment in man in relation to epidemiological conditions: Nordrhein-Westfalen 1972. Zentralbl Bakteriol (Orig A) 231:15-30, 1975

71. Wachendörfer G: Die gegenwärtige Situation und Bedeutung der Tollwut in der Bundesrepublik Deutschland. DTW 84:413-452, 1977

72. Selimov M, Tatarov A, Ilyasova R, et al: Problems of natural foci of sylvatic and arctic rabies. Background document, WHO Consultations on Rabies Preventions and Control. Lyon, March, 1980

73. Cerkasskij VL: The role of the racoon dog in the epizootiology and epidemiology of rabies. Un published document. Geneva, WHO Veterinary Public Health Service, 1980 